\title{
$1 \quad$ Peptidergic signaling in the crab Cancer borealis: tapping 2 the power of transcriptomics for neuropeptidome expansion
}

\author{
Andrew E. Christie* and Micah G. Pascual
}

Békésy Laboratory of Neurobiology, Pacific Biosciences Research Center, School of Ocean and Earth Science and Technology, University of Hawaii at Manoa, 1993 East-West Road, Honolulu, HI 96822 USA

*Correspondence to: Dr. Andrew E. Christie, Békésy Laboratory of Neurobiology, Pacific Biosciences Research Center, School of Ocean and Earth Science and Technology, University of Hawaii at Manoa, 1993 East-West Road, Honolulu, HI 96822 USA. Phone: 808-956-5212;

FAX: 808-956-6984; Email: crabman@ pbrc.hawaii.edu

Key words: transcriptomics; bioinformatics; neuropeptide; neurohormone; Crustacea; Decapoda 


\section{Abstract}

The crab Cancer borealis has long been used as a model for understanding neural control

23 of rhythmic behavior. One significant discovery made through its use is that even numerically

24 simple neural circuits are capable of producing an essentially infinite array of distinct motor

25 outputs via the actions of locally released and circulating neuromodulators, the largest class

26 being peptides. While much work has focused on elucidating the peptidome of $C$. borealis, no

27 investigation has used in silico transcriptome mining for peptide discovery in this species, a

28 strategy proven highly effective for identifying neuropeptides in other crustaceans. Here, we

29 mined a $C$. borealis neural transcriptome for putative peptide-encoding transcripts, and predicted

30200 distinct mature neuropeptides from the proteins deduced from these sequences. The

31 identified peptides include isoforms of allatostatin $\mathrm{A}$, allatostatin $\mathrm{B}$, allatostatin $\mathrm{C}$, CCHamide,

32 crustacean cardioactive peptide, crustacean hyperglycemic hormone, diuretic hormone 31

33 (DH31), diuretic hormone 44 (DH44), FMRFamide-like peptide, GSEFLamide,

34 HIGSLYRamide, insulin-like peptide (ILP), intocin, leucokinin, neuroparsin, pigment dispersing

35 hormone, pyrokinin, red pigment concentrating hormone, short neuropeptide F and SIFamide.

36 While some of the predicted peptides were known previously from C. borealis, most (159) are

37 new discoveries for the species, e.g., the isoforms of CCHamide, DH31, DH44, GSEFLamide,

38 ILP, intocin and neuroparsin, which are the first members of these peptide families identified

39 from $C$. borealis. Collectively, the peptides predicted here approximately double the peptidome

40 known for $C$. borealis, and in so doing provide an expanded platform from which to launch new

41 investigations of peptidergic neuromodulation in this species.

\section{1. Introduction}


The nervous systems of crustaceans, particularly members of the Decapoda, have been

45 used for over half a century for investigating the neural control of physiology and behavior. One

46 area where they have proven particularly useful is in elucidating the basic principles that govern

47 the generation, maintenance and modulation of rhythmic behavior, i.e., control of motor systems

48 that produce behaviors such as walking, chewing and breathing in humans. The stomatogastric

49 and cardiac neural circuits of decapods, which control the rhythmic movements of the foregut

50 and heart musculatures, respectively, are arguably the best understood in the animal kingdom

51 (for review see: Blitz and Nusbaum, 2011; Christie, 2011; Christie et al., 2010a; Cooke, 2002;

52 Fénelon et al., 2003; Hooper and DiCaprio, 2004; Marder and Bucher, 2007; Marder et al., 1995;

53 Nusbaum et al., 2001; Selverston, 2005; Selverston and Ayers, 2006; Selverston et al., 1998;

54 Skiebe, 2001; Stein, 2009). Both of these systems consist of very small numbers of relatively

55 large neurons (the stomatogastric network consists of $\sim 25$ neurons, depending on the species in

56 question, with the cardiac ganglion containing just nine nerve cells), and this tractability for

57 investigation at the cellular and systems levels has allowed for the connectivity between network

58 elements to be fully worked out for several species. One of the major insights gained from work

59 on the decapod stomatogastric and cardiac systems is that a simple "hardwired" neural circuit is

60 capable of producing diverse motor output, i.e., one circuit driving an essentially infinite array of

61 distinct behaviors. While a number of factors undoubtedly contribute to this functional

62 flexibility, much is attributable to the actions of neuromodulators, locally released and

63 circulating substances that are capable of reconfiguring a neural network by changing the

64 properties of the individual circuit elements. Several classes of neuromodulators have been

65 identified in crustaceans, including small molecule transmitters, biogenic amines and diffusible 
gases (e.g., Christie, 2011). However, the largest and most diverse group of these compounds is

67 the peptides (e.g., Christie, 2011; Christie et al., 2010a; Skiebe, 2001).

The brachyuran crab Cancer borealis is one of the most commonly used decapods for

69 studies of neuromodulation (e.g., Blitz and Nusbaum, 2011; Christie, 2011; Christie et al., 2010a;

70 Fénelon et al., 2003; Hooper and DiCaprio, 2004; Marder and Bucher, 2007; Marder et al., 1995;

71 Nusbaum et al., 2001; Selverston, 2005; Selverston and Ayers, 2006; Selverston et al., 1998;

72 Skiebe, 2001; Stein, 2009). Not surprisingly, much work has focused on identifying and

73 characterizing the native neuropeptides present in this species (e.g., Christie et al., 1997; Cruz-

74 Bermúdez et al., 2006; Dickinson et al., 2009a; Fu et al., 2005a, 2007; Huybrechts et al., 2003;

75 Li et al., 2002, 2003; Ma et al., 2009a, 2009b, 2009c, 2009d; Marder et al., 1986; Saideman et

76 al., 2007; Stemmler et al., 2005, 2007a, 2007b, 2007c, 2010; Szabo et al., 2011; Weimann et al.,

77 1993), with most studies using mass spectrometry, in particular accurate mass matching and/or

78 de novo tandem mass spectrometric sequencing, for peptide discovery (e.g., Cruz-Bermúdez et

79 al., 2006; Dickinson et al., 2009a; Fu et al., 2005a, 2007; Huybrechts et al., 2003; Li et al., 2002,

80 2003; Ma et al., 2009a, 2009b, 2009c, 2009d; Saideman et al., 2007; Stemmler et al., 2005,

81 2007a, 2007b, 2007c, 2010; Szabo et al., 2011). This work has identified a diverse

82 neuropeptidome for $C$. borealis, which, prior to the study presented here, consisted of 150 or so

83 distinct neuropeptides and encompassed approximately 20 different peptide families, e.g.,

84 allatostatin A (AST-A), allatostatin B (AST-B), allatostatin C (AST-C), corazonin, crustacean

85 cardioactive peptide (CCAP), crustacean hyperglycemic hormone $(\mathrm{CHH}) /$ molt-inhibiting

86 hormone (MIH), crustacean hyperglycemic hormone precursor-related peptide (CPRP),

87 FMRFamide-like peptide (FLP), HIGSLYRamide, leucokinin, myosuppressin, orcokinin,

88 orcomyotropin, pigment dispersing hormone (PDH), proctolin, pyrokinin, red pigment 
concentrating hormone (RPCH), RYamide, short neuropeptide F (sNPF), SIFamide and

90 tachykinin-related peptide (TRP).

91 While a powerful tool, peptide identification by mass spectrometry can, in some cases, be

92 limited by the abundance of a peptide, its ionization efficiency, the post-translational

93 modifications present in it, and/or by its length. For these "problematic" peptides, in silico

94 prediction from high-throughput nucleotide sequence data offers an alternative means of

95 discovery (e.g., Christie et al., 2010a). Via this strategy, large peptidomes that include low

96 abundance, difficult to ionize, heavily modified and/or long peptides have recently been

97 predicted for a variety of species, including many crustaceans (e.g., Bao et al., 2015; Christie,

98 2014a, 2014b, 2014c, 2014d, 2014e, 2014f, 2015a, 2016a, 2016b; Christie and Chi, 2015a;

99 Christie et al., 2013, 2015, 2016; Gard et al., 2009; Ma et al., 2009e, 2010; Suwansa-Ard et al.,

100 2015; Toullec et al., 2013; Veenstra, 2015; Ventura et al., 2014; Yan et al., 2012). Not

101 surprisingly, the current $C$. borealis peptidome is missing peptides from families that might well

102 be problematic to discover via mass spectral means. Thus, to complement and augment the

103 extant peptidome for this species, we mined a publicly accessible $C$. borealis neural

104 transcriptome (BioProject No. PRJNA310325; Northcutt et al., 2016) for sequences encoding

105 putative neuropeptide precursors, and then used the proteins deduced from these transcripts to

106 predict the mature structures of peptide isoforms.

107 As the data that follow will show, 25 transcripts encoding putative peptide precursors

108 were identified within the $C$. borealis transcriptome shotgun assembly (TSA) dataset. The

109 proteins deduced from these sequences allowed for the prediction of 200 distinct mature

110 peptides, 159 being novel discoveries for this species. The identified peptides included members

111 of 20 different families, seven of which, CCHamide, diuretic hormone 31 (DH31), diuretic 
112 hormone 44 (DH44), GSEFLamide, insulin-like peptide (ILP), intocin and neuroparsin, are new

113 to $C$. borealis. The peptides predicted here approximately double the known C. borealis

114 neuropeptidome, and in so doing provide an expanded platform for investigating peptidergic

115 control of physiology and behavior in this important biomedical model.

116

\section{2. Materials and methods}

$118 \quad$ 2.1. Database searches

119 Database searches were conducted on or before April 14, 2016, using methods modified

120 from a well-vetted protocol (e.g., Christie, 2008a, 2008b, 2014a, 2014b, 2014c, 2014d, 2014e,

121 2014f, 2015a, 2015b, 2015c, 2015d, 2016a, 2016b; Christie and Chi, 2015a, 2015b, 2015c;

122 Christie et al., 2008a, 2010b, 2011a, 2011b, 2013, 2015, 2016; Gard et al., 2009; Ma et al.,

123 2009e, 2010). Specifically, the database of the online program tblastn (National Center for

124 Biotechnology Information, Bethesda, MD; http://blast.ncbi.nlm.nih.gov/Blast.cgi) was set to

125 "Transcriptome Shotgun Assembly (TSA)" and restricted to data from "Cancer borealis

126 (taxid:39395)". Known crustacean peptide precursors were input into tblastn as the query

127 sequences, and all hits returned by a given search were fully translated using the "Translate" tool

128 of ExPASy (http://web.expasy.org/translate/), and then checked manually for homology to the

129 target query. The complete list of peptide families searched for in this study, as well as the

130 specific queries used, is provided in Table 1; this table also provides the BLAST-generated

131 maximum score and E-value for each of the transcripts identified as encoding a putative

132 neuropeptide precursor.

133

134 2.2. Peptide prediction 
136 Christie, 2008a, 2008b, 2014a, 2014b, 2014c, 2014d, 2014e, 2014f, 2015a, 2015b, 2015c, 2015d,

137 2016a, 2016b; Christie and Chi, 2015a, 2015b, 2015c; Christie et al., 2008a, 2010b, 2011a,

138 2011b 2011c, 2013, 2015, 2016; Gard et al., 2009; Ma et al., 2009e, 2010). Specifically, each of

139 the deduced precursor proteins was assessed for the presence of a signal peptide using the online

140 program SignalP 4.1 (http://www.cbs.dtu.dk/services/SignalP/; Petersen et al., 2011); the D-

141 cutoff values of SignalP 4.1 were set to "Sensitive" to better match the sensitivity of version 3.0

142 of this freeware program. Prohormone cleavage sites were identified based on the information

143 presented in Veenstra (2000) and/or by homology to known arthropod pre/preprohormone

144 processing schemes. When present, prediction of the sulfation state of tyrosine residues was

145 conducted using the online program "Sulfinator" (http://www.expasy.org/tools/sulfinator/;

146 Monigatti et al., 2002). Disulfide bonding between cysteine residues was predicted by

147 homology to known peptide isoforms and/or by using the online program "DiANNA"

148 (http://clavius.bc.edu/ clotelab/DiANNA/; Ferrè and Clote, 2005). Other post-translational

149 modifications, i.e., cyclization of amino (N)-terminal glutamine/glutamic acid residues and

150 carboxyl (C)-terminal amidation at glycine residues, were predicted by homology to known

151 arthropod peptide isoforms. Figure 1 shows three examples of mature peptide structural

152 prediction using the workflow just described; the mature structures of all peptides predicted in

153 this study are provided in Table 2. All protein/peptide alignments were done using the online

154 program MAFFT version 7 (http://mafft.cbrc.jp/alignment/software/; Katoh and Standley, 2013). 
158 C. borealis TSA dataset (Table 1). In the interest of space, only those searches that resulted in

159 the identification of putative precursor-encoding transcripts are described here, with the data

160 presented in alphabetical order based on family name. All proteins listed as "full-length" exhibit

161 a functional signal sequence (including a "start" methionine) and are flanked on their C-terminal

162 end by a stop codon. Proteins described here as "partial" lacked a start methionine (referred to as

163 C-terminal partial proteins), a stop codon (referred to as N-terminal partial proteins), or both of

164 these features (referred to as internal fragment proteins).

165

\subsection{Allatostatin A (AST-A)}

167 One transcript was identified as encoding a putative AST-A precursor (Table 1).

168 Translation of this transcript revealed a partial protein whose sequence is split between three

169 translation frames $(+1,+2$ and +3$)$, all treated here as internal fragments of the same

170 preprohormone (Canbo-prepro-AST-A; Fig. 2A); the length of the three combined fragments is

171709 amino acids. Forty-nine distinct peptides were predicted from Canbo-prepro-AST-A (Table

1722 and Fig. 2A), thirty of which possess the C-terminal motif-YXFGLamide (or a close

173 approximation thereof), the hallmark of the AST-A family (Christie et al., 2010a). Of the AST-

174 As predicted here, eighteen, pEPYAFGLamide, PATDLYAFGLamide, DPYAFGLamide,

175 PADLYEFGLamide, GDPYAFGLamide, PDMYAFGLamide, SSGQYAFGLamide,

176 PSMYAFGLamide, PDMYGFGLamide, GSGQYAFGLamide, DRPYSFGLamide,

177 APQPYAFGLamide, AGLYSYGLamide, SDMYSFGLamide, PRDYAFGLamide,

178 pQRAYSFGLamide, pQRDYSFGLamide and AGPYSFGLamide, are previously known $C$.

179 borealis peptides (e.g., Ma et al., 2009b). 
3.2. Allatostatin $B(A S T-B)$

Two transcripts were identified as encoding putative AST-B precursors (Table 1).

183 Translation of one of these sequences revealed a 195 amino acid N-terminal partial

184 preprohormone, while translation of the other revealed a 43 amino acid C-terminal partial

185 protein. Given no obvious area of overlap, these two partial precursors are considered here to be 186 from different proteins and have been named Canbo-prepro-AST-B I (Fig. 2B1) and Canbo-

187 prepro-AST-B II (Fig. 2B2), respectively. Seventeen distinct peptides (15 full-length and two

188 partial) were predicted for this set of partial preprohormones (Table 2 and Fig. 2B), eight of

189 which possess the C-terminal motif $-\mathrm{W} X_{6}$ Wamide, the hallmark of members of the AST-B

190 family (Christie et al., 2010a); based on their extant sequences, the two partial peptides are likely

191 to be members of the AST-B family as well, and are included as such in Table 2. Of the

192 predicted AST-Bs, six, NNNWSKFQGSWamide, GNWNKFQGSWamide,

193 TSWGKFQGSWamide, NNWSKFQGSWamide, SGKWSNLRGAWamide and

194 VPNDWAHFRGSWamide, are reidentifications of known C. borealis peptides (e.g., Ma et al., 195 2009b).

197 3.3. Allatostatin C (AST-C)

198 Two transcripts were identified as encoding putative AST-C precursors (Table 1).

199 Translation of one sequence revealed a 150 amino acid full-length preprohormone (Canbo-

200 prepro-AST-C I; Fig. 1A), while translation of the other revealed a 56 amino acid C-terminal

201 partial protein (Canbo-prepro-AST-C II; Fig. 2C). Nine distinct peptides were predicted from

202 the combination of the two precursor proteins (Table 2 and Figs. 1A and 2C), including 
203 pQIRYHQCYFNPISCF (a disulfide bridge between the two cysteines) from Canbo-prepro-AST-

204 C I and SYWKQCAFNAVSCFamide (disulfide bonding between the cysteine residues) from

205 Canbo-prepro-AST-C II, both previously known C. borealis AST-C isoforms (e.g., Dickinson et

206 al., 2009a; Ma et al., 2009c; Stemmler et al., 2010).

207

208 3.4. CCHamide

209 One transcript was identified as encoding a putative CCHamide precursor (Table 1).

210 Translation of this sequence revealed a 195 amino acid full-length preprohormone (Canbo-

211 prepro-CCHamide; Fig. 2D). Five distinct peptides were predicted from Canbo-prepro-

212 CCHamide (Table 2 and Fig. 2D), including one, HGPVKVGCLNYGHSCLGAHamide (a

213 disulfide bridge between the two cysteines), that possess the structural hallmarks of an N-

214 terminally extended CCHamide, i.e., the consensus motif XCXXW/Y/FGXXCXGXHamide and

215 disulfide bridging between the two cysteine residues (Hansen et al., 2011).

216

217 3.5. Crustacean cardioactive peptide (CCAP)

218 One transcript was identified as encoding a putative CCAP precursor (Table 1).

219 Translation of this sequence revealed a 142 amino acid full-length preprohormone (Canbo-

220 prepro-CCAP; Fig. 2E). Six distinct peptides were predicted from Canbo-prepro-CCAP (Table 2

221 and Fig. 2E), including PFCNAFTGCamide (a disulfide bridge between the two cysteines),

222 which is identical in structure to authentic CCAP (Christie et al., 2010a), a peptide identified

223 previously from C. borealis (e.g., Li et al., 2003).

224

225 3.6. Crustacean hyperglycemic hormone (CHH)/molt-inhibiting hormone (MIH) 
One transcript was identified as encoding a putative $\mathrm{CHH}$ precursor (Table 1).

227 Translation of this sequence revealed a 130 amino acid full-length protein (Canbo-prepro-CHH;

228 Fig. 2F). Two distinct peptides were predicted from Canbo-prepro-CHH (Table 2 and Fig. 2F),

229 one of which,

230 APIVDSSCKGQYSMYIWNKLYFVCEDCTNIFRTDGFEAQCRQGCFDTDIFAKCLRELSK

231 DVNEYQIMATSLRGS, is 52\% identical/81\% similar in amino acid sequence to an isoform of

$232 \mathrm{CHH}$ recently identified from a preprohormone from the crab Scylla paramamosain (Accession

233 No. $\underline{\mathbf{A L Q 2 8 5 8 2}}$; Bao et al., 2015), i.e.,

234 ATDLVDTSCKGYYDRDTWNELHHLCEDCDNLYRQFHFQAKCRSDCFASDVFATCLTD

235 LGKNVEIYQAMAASLRGS. Analysis of this $C$. borealis $\mathrm{CHH}$ using the online program

236 DiANNA suggests disulfide bridges are present between its first and fifth, second and fourth, and

237 third and sixth cysteine residues, a pattern of bonding considered stereotypical of members of the 238 CHH family (Böcking et al., 2002).

\subsection{Diuretic hormone 31 (DH31)}

241 One transcript was identified as encoding a putative DH31 precursor (Table 1).

242 Translation of this sequence revealed a 146 amino acid full-length preprohormone (Canbo-

243 prepro-DH31; Fig 1B). Four distinct peptides were predicted from Canbo-prepro-DH31 (Table 2

244 and Fig. 1B), one of which, GLDMGLGRGFSGSQAAKHLMGIAAANYAGGPamide,

245 possesses the structural hallmarks of a DH31 family member (Christie et al., 2010a), i.e., an

246 overall length of 31 amino acids, an amidated C-terminus, and 13 highly conserved residues

247 ( $X X \mathrm{D} X \mathrm{GL} X \mathrm{RG} X \mathrm{SG} X X X \mathrm{AK} X X X X X X X \mathrm{AN} X X X \mathrm{GPamide})$. 
One transcript was identified as encoding a putative DH44 precursor (Table 1).

251 Translation of this sequence revealed a 327 amino acid full-length preprohormone (Canbo-

252 prepro-DH44; Fig. 2G). Nine distinct peptides were predicted from Canbo-prepro-DH44 (Table

2532 and Fig. 2G), including one,

254 SSGLSLSIDASMKVLREALYLEIARKKQRQQLQRAQHNKALLNTIamide, that is similar in 255 sequence to known members of the DH44 family, i.e., the isoform of DH44

256 (NTGLSLSIDASMKVLREALYLEIARKKQRQQLQRAQHNKALLNTIamide; Christie,

257 2016b) that was predicted from the C. maenas precursor used to identify the transcript encoding

258 Canbo-prepro-DH44.

\subsection{FMRFamide-like peptide (FLP)}

One transcript was identified as encoding a putative FLP precursor (Table 1). Translation

262 of this sequence revealed a 264 amino acid C-terminal partial protein (Canbo-prepro-FLP; Fig.

263 2H). Fifteen distinct peptides were predicted from Canbo-prepro-FLP (Table 2 and Fig. 2H),

264 eight of which possess -F/YLRFamide C-termini, endings commonly seen in decapod FLPs

265 (Christie et al., 2010a). One other of the predicted peptides, +SSSEEDKHRFamide (a partial

266 sequence) possesses a-KHRFamide C-terminus, and likely represents a portion of a novel FLP

267 variant. Seven of the FLPs predicted here, NRNFLRFamide, GAHKNYLRFamide,

268 GNRNFLRFamide, SENRNFLRFamide, AYNRSFLRFamide, DRNFLRFamide and

269 APQRNFLRFamide, are known C. borealis isoforms (e.g., Cruz-Bermúdez et al., 2006;

270 Huybrechts et al., 2003; Li et al., 2003; Ma et al., 2009b). 
273 One transcript was identified as encoding a putative GSEFLamide precursor (Table 1).

274 Translation of this sequence revealed a 182 amino acid N-terminal partial protein (Canbo-prepro-

275 GSEFLamide; Fig. 2I). Ten distinct peptides (nine full-length and one partial) were predicted

276 from Canbo-prepro-GSEFLamide (Table 2 and Fig. 2I), including IGSEFLamide and

277 MGSEFLamide, two members of the GSEFLamide family.

\subsection{HIGSLYRamide}

280 One transcript was identified as encoding a putative HIGSLYRamide precursor (Table 1).

281 Translation of this sequence revealed a 760 amino acid N-terminal partial protein (Canbo-prepro-

282 HIGSLYRamide; Fig. 2J). Twenty-five distinct peptides were predicted from Canbo-prepro-

283 HIGSLYRamide (Table 2 and Fig. 2J), including HIGSLYRamide itself (a peptide previously

284 identified from C. borealis [e.g., Ma et al., 2009b]), and its variants HIGSLYRS, HIGSLYRD,

285 HYSSLLRamide and HIGSLYLSED. It should be noted that the partial peptide HI+ was also

286 predicted from Canbo-prepro-HIGSLYRamide; it is likely that HI+ is a portion of

287 HIGSLYRamide (or one of the related sequences), and hence it has not been included in Table 2.

289 3.12. Insulin-like peptide (ILP)

290 One transcript was identified as encoding a putative ILP precursor (Table 1). Translation

291 of this sequence revealed a 165 amino acid full-length preprohormone (Canbo-prepro-ILP; Fig.

292 2K). Five distinct peptides were predicted from Canbo-prepro-ILP (Table 2 and Fig. 2K),

293 including the A-chain ILP isoform GLSAECCRKACSVSELAGYCY (a disulfide bridge

294 between the first and third cysteines) and the B-chain ILP isoform 
296 crustacean ILPs (e.g., Dircksen et al., 2011), it is presumed that the bioactive ILP hormone

297 consists of a heterodimer formed by disulfide bridging between the A- and B-chain peptides (the 298 first cysteine in LCGWKLANELNRVCKGVYNKPTVSTNALFYLKERGamide bridged to the 299 second cysteine in the A-chain and the second cysteine in this peptide bridged to the fourth 300 cysteine in the A-chain; these interpeptide bridged cysteines are not highlighted in the peptide 301 structures shown in Table 2).

\subsection{Intocin}

One transcript was identified as encoding a putative intocin precursor (Table 1).

305 Translation of this sequence revealed a 157 amino acid full-length preprohormone (Canbo-

306 prepro-intocin; Fig. 2L). Six distinct peptides were predicted from Canbo-prepro-intocin (Table 3072 and Fig. 2L), one of which, CFITNCPPGamide (disulfide bridging between the two cysteines), 308 possesses the structural hallmarks of an intocin family member (Stafflinger et al., 2008), i.e., an 309 overall length of nine amino acids, the structure CXXXNCPXGamide, and a disulfide bridge 310 present between the position 1 and 6 cysteine residues. It should be noted that in two of the 311 intocin linker/precursor-related peptides, multiple disulfide bridges were predicted by DiANNA, 312 i.e., the first and third, second and fourth, and fifth and sixth cysteines bridged in

313 SGGLMSQLGRARTCTSCGPGLLGRCIGPDICCGPRIGCFLGSRET, and the first and second 314 and fourth and fifth cysteines bridged in

315 CAAPGLCCTENKCEINDDCVVDTRGEDMSTSQRGamide (Table 2). 316 317 3.14. Leucokinin 
One transcript was identified as encoding a putative leucokinin precursor (Table 1).

319 Translation of this sequence revealed a 116 amino acid C-terminal partial protein (Canbo-prepro-

320 leucokinin; Fig. 2M). Five distinct peptides were predicted from this partial preprohormone

321 (Table 2 and Fig. 2M), two of which, FNAWAamide and the partial peptide +SAWAamide (a

322 partial peptide), possess the C-terminal motif-FXXWA/Gamide (or at least most of it), the

323 hallmark of the leucokinin family (Christie et al., 2010a).

\subsection{Neuroparsin}

Four transcripts were identified as encoding putative neuroparsin precursors (Table 1).

327 Translation of these transcripts revealed three to encode 101 amino acid full-length proteins

328 (Canbo-pre-neuroparsin I [Fig. 2N1], Canbo-pre-neuroparsin II [Fig. 2N2] and Canbo-pre-

329 neuroparsin III [Fig. 2N3]), all distinct in sequence, and the fourth, a 104 amino acid full-length

330 prehormone (Canbo-pre-neuroparsin IV [Fig. 2N4]). A single isoform of neuroparsin was

331 predicted from each of the four prehormones, again, each possessing a unique sequence (Table 2

332 and Fig. 2N). Analysis of the neuroparsin isoform derived from Canbo-pre-neuroparsin I by

333 DiANNA suggests disulfide bridging between its first and second, third and sixth, fourth and

334 eleventh, fifth and seventh, eighth and tenth, and ninth and twelfth cysteine residues, while the

335 first and tenth, second and fourth, third and eighth, fifth and seventh, sixth and twelfth, and ninth 336 and eleventh cysteines are predicted to be bridged in the peptide derived from Canbo-pre-

337 neuroparsin II (Table 2). The first and twelfth, second and tenth, third and sixth, fourth and fifth, 338 seventh and ninth, and eight and eleventh cysteines are predicted to be bonded in the neuroparsin 339 predicted from Canbo-pre-neuroparsin III, while the first and twelfth, second and third, fourth 
340 and sixth, fifth and seventh, eighth and eleventh, and ninth and tenth cysteines are predicted to be

341 bridged in the isoform derived Canbo-pre-neuroparsin IV (Table 2).

\section{3.16. Pigment dispersing hormone}

344 One transcript was identified as encoding a putative PDH precursor (Table 1).

345 Translation of this sequence revealed a 78 amino acid full-length preprohormone (Canbo-prepro-

346 PDH; Fig. 2O). Two peptides were predicted from Canbo-prepro-PDH (Table 2 and Fig. 2O),

347 one of which, NSELINSILGLPKVMNDAamide, is identical in structure to authentic $\beta$-PDH

348 (Christie et al., 2010a), a previously identified C. borealis peptide (e.g., Ma et al., 2009b).

350 3.17. Pyrokinin

351 One transcript was identified as encoding a putative pyrokinin precursor (Table 1).

352 Translation of this sequence revealed a 338 amino acid full-length preprohormone (Canbo-

353 prepro-pyrokinin; Fig. 2P). Sixteen distinct peptides were predicted from Canbo-prepro-

354 pyrokinin (Table 2 and Fig. 2P), ten of which possess the C-terminal motif-FXPRXamide, the 355 hallmark of the pyrokinin family (Rafaeli, 2009). Two of the pyrokinins predicted here,

356 LYFAPRLamide and TNFAFSPRLamide, are known C. borealis peptides (Ma et al., 2009b;

357 Saideman et al., 2007).

359 3.18. Red pigment concentrating hormone (RPCH)

360 One transcript was identified as encoding a putative RPCH precursor (Table 1).

361 Translation of this sequence revealed a 109 amino acid full-length preprohormone (Canbo-

362 prepro-RPCH; Fig. 2Q). Three distinct peptides were predicted from Canbo-prepro-RPCH 
363 (Table 2 and Fig. 2Q), one of which, pQLNFSPGWamide, is identical in structure to authentic

364 RPCH (Christie et al., 2010a), a known C. borealis peptide (e.g., Li et al., 2003).

365

366 3.19. Short neuropeptide F (sNPF)

367 One transcript was identified as encoding a putative sNPF precursor (Table 1).

368 Translation of this sequence revealed a 125 amino acid full-length preprohormone (Canbo-

369 prepro-sNPF; Fig. 1C). Six distinct peptides were predicted from Canbo-prepro-sNPF (Table 2

370 and Fig. 1C), three of which possess the structural hallmarks of sNPF family members (Christie

371 et al., 2010a), i.e., the C-terminal motif -RLRFamide and an overall length of approximately 10

372 amino acids. One of the sNPFs predicted here, DVRTPALRLRFamide, is a previously known

373 C. borealis peptide (e.g., Huybrechts et al., 2003).

374

375 3.20. SIFamide

376 One transcript was identified as encoding a putative SIFamide precursor (Table 1).

377 Translation of this transcript revealed a 78 amino acid full-length preprohormone (Canbo-prepro-

378 SIFamide; Fig. 2R). Two peptides were predicted from Canbo-prepro-SIFamide (Table 2 and

379 Fig. 2R), one of which, GYRKPPFNGSIFamide, is a known C. borealis isoform of SIFamide

380 (e.g., Huybrechts et al., 2003).

381

382 4. Discussion

383 4.1. Expansion of the neuropeptidome of Cancer borealis

384 Due to its status as a model for studies of neuromodulation, much work has focused on

385 identifying the native neuropeptides of C. borealis (e.g., Christie et al., 1997; Cruz-Bermúdez et 
al., 2006; Dickinson et al., 2009a; Fu et al., 2005a, 2007; Huybrechts et al., 2003; Li et al., 2002, 2003; Ma et al., 2009a, 2009b, 2009c, 2009d; Marder et al., 1986; Saideman et al., 2007; Stemmler et al., 2005, 2007a, 2007b, 2007c, 2010; Szabo et al., 2011; Weimann et al., 1993). In total, approximately 150 different neuropeptides were known from this species prior to our study, most identified via mass spectral means (e.g., Cruz-Bermúdez et al., 2006; Dickinson et al., 2009a; Fu et al., 2005a, 2007; Huybrechts et al., 2003; Li et al., 2002, 2003; Ma et al., 2009a, 2009b, 2009c, 2009d; Saideman et al., 2007; Stemmler et al., 2005, 2007a, 2007b, 2007c, 2010;

393 Szabo et al., 2011). While a powerful platform for peptide discovery, mass spectrometry does

394 have limitations for the detection and characterization of some types of neuropeptides, e.g., those 395 that do not ionize well. Thus, to complement the peptidomic analyses conducted using mass 396 spectrometry, we employed in silico transcriptome mining/bioinformatics peptide prediction to 397 identify and characterize $C$. borealis neuropeptides, a strategy that does not have the same 398 limitations as mass spectral approaches (e.g., Christie et al., 2010a). Via the mining of a publicly accessible neural transcriptome for C. borealis (BioProject No. PRJNA310325; Northcutt et al., 2016), 25 transcripts were identified as encoding putative peptide precursors. Translation of these sequences, and subsequent analyses of the proteins deduced from them using a bioinformatics peptide prediction pipeline, allowed for the prediction 403 of 200 distinct neuropeptides. This peptidome includes isoforms of AST-A (30), AST-B (10), 404 AST-C (two), CCHamide (one), CCAP (one), CHH (one), CPRP (one), DH31 (one), DH44 405 (one), FLP (nine), GSEFLamide (two), HIGSLYRamide (five), ILP (one A- and one B-chain), 406 intocin (1), leucokinin (two), neuroparsin (four), PDH (one), pyrokinin (10), RPCH (one), sNPF 407 (three) and SIFamide (one), as well as many linker/precursor-related sequences that may or may 408 not represent bioactive neuropeptides. Of particular note was our identification of isoforms of 
CCHamide, DH31, DH44, GSEFLamide, ILP, intocin and neuroparsin, which are the first

410 members of these peptide groups identified from C. borealis. In fact, of the 200 peptides

411 predicted here, 159 are new discoveries for this species, which essentially doubles the peptidome

412 extant for C. borealis prior to our study.

413 While we did not expect to find transcripts encoding members of the DENamide,

414 DXXRLamide or FXGGXamide families as they have thus far been identified from very limited

415 sets of crustaceans (Christie, 2014b, 2014d, 2015a; Dircksen et al., 2011), e.g., DENamides are

416 currently know from just a single species, i.e., the cladoceran Daphnia pulex (Dircksen et al.,

417 2011), corazonin-, myosuppressin-, orcokinin-, proctolin-, RYamide- and TRP-encoding

418 transcripts must be present in C. borealis, as one or more isoforms of each of these peptide

419 groups are known from this species (e.g., Ma et al., 2009b). It is possible that our lack of

420 detection of them was due to incomplete coverage of the transcriptome that we mined and/or that

421 the peptides in question are not present in the tissues used to produce the TSA dataset; the brain,

422 stomatogastric nervous system and cardiac nervous system were included in the transcriptome,

423 the eyestalk ganglia and fused thoracic/abdominal ganglionic ring (the locations of many

424 neuroendocrine somata (e.g., Christie, 2011) were not (Northcutt et al., 2016). It also seems

425 likely that members of the allatotropin, bursicon $\alpha$, bursicon $\beta$, eclosion hormone, neuropeptide

426 F and sulfakinin families are present in C. borealis, as members of these groups appear broadly

427 conserved in decapod species (e.g., Bao et al., 2015; Christie, 2014f, 2016a, 2016b; Christie and

428 Chi, 2015a; Christie et al., 2015; Fu et al., 2005b; Ma et al., 2010; Suwansa-Ard et al., 2015;

429 Ventura et al., 2014). As additional molecular data are generated for C. borealis (particularly

430 from portions of the nervous system not yet investigated), it will be interesting to see what other 
431 neuropeptides can be identified from it, and ultimately how large and diverse a neuropeptidome

432 this important biomedical model actually possesses.

434 4.2. A revisitation of mass spectral sequence assignments in light of in silico peptide predictions

435 One concern for peptide discovery using mass spectrometry is whether a deduced

436 structural assignment represents the true bioactive conformation of the peptide in question, or if

437 the assigned structure is a methodological artifact, represents an immature peptide or is a

438 degradation product of a mature bioactive molecule. The identification of full-length precursor

439 proteins, and the bioinformatics prediction of the peptides they are likely to liberate, can help

440 resolve these issues, and the $C$. borealis data presented here allow for a revisitation of several

441 earlier mass spectral peptide identifications.

442 Four isoforms of pyrokinin have been identified from C. borealis using mass

443 spectrometry, TNFAFSPRLamide, SGGFAFSPRLamide, LYFAPRLamide and FSPRLamide

444 (e.g., Ma et al., 2009b; Saideman et al., 2007). Both TNFAFSPRLamide and LYFAPRLamide

445 were reidentified here from Canbo-prepro-pyrokinin. However, neither FSPRLamide nor

446 SGGFAFSPRLamide were among the eight other pyrokinins predicted from this full-length

447 preprohormone. Given that three of the pyrokinins predicted from Canbo-prepro-pyrokinin

448 possess -FSPRLamide C-termini (i.e., SSFSPRPamide, GSGFAFSPRLamide and

449 TNFAFSPRLamide), it is highly likely that FSPRLamide is a fragment of one or more of these

450 full-length peptides rather than being a mature, full-length signaling molecule itself. Whether

451 the FSPRLamide fragment is a natural proteolytic degradation product of the larger peptides or is

452 an artifact produced by the extraction process or by the mass spectral instrumentation remains

453 unknown, though all are certainly plausible mechanisms for its generation. 
The pyrokinin identified as SGGFAFSPRLamide by mass spectrometry (referred to as

455 CabPK II in the original publication describing it [Saideman et al., 2007]) is almost certainly the 456 GSGFAFSPRLamide isoform predicted here; the two peptides differ only in that their first two

457 residues are reversed in their order. The sequence of CabPK II was originally determined using 458 capillary liquid chromatography coupled with quadrupole time-of-flight tandem mass

459 spectrometry (MS/MS), with the fragment ions produced via this platform clearly supporting the 460 C-terminus of this peptide being FAFSPRLamide. The N-terminus of CabPK II was reported to 461 be problematic to characterize because of weak and missing fragment ions, which Saideman et 462 al. [2007] attributed to the presence of the two glycines in this portion of the peptide's sequence. 463 The N-terminus was ultimately assigned as SGG based on an internal fragment ion that was 464 believed to correspond to GG (m/z 115.091). In the figure showing the MS/MS fragmentation of 465 native CabPK II (Fig. 3B of Saideman et al. [2007]), we do not see any real evidence of a peak 466 corresponding to $\mathrm{m} / \mathrm{z}$ 115.091. Moreover, it does not appear that a synthetic standard of CabPK 467 II (i.e., SGGFAFSPRLamide) was analyzed, which should have revealed any discrepancies 468 between chromatographic retention time and MS/MS fragmentation of the native and synthetic 469 peptides. Thus, we believe the SGG N-terminus reported for CabPK II by Saideman et al. 470 [2007] is likely in error, and that the actual structure of the peptide is GSGFAFSPRLamide, the 471 structure predicted here via our bioinformatics workflow.

472 The identification of a full-length precursor protein for sNPF also allowed for a revisiting 473 of the isoforms of this peptide family that have been identified from C. borealis using mass 474 spectrometry, i.e., DVRTPALRLRFamide, SMPSLRLRFamide, PSLRLRFamide and 475 PSMRLRFamide (e.g., Huybrechts et al., 2003; Ma et al., 2009b). Of these four peptides, only 476 DVRTPALRLRFamide was reidentified as a full-length sNPF in our in silico analyses. 
SMPSLRLRFamide, PSLRLRFamide and PSMRLRFamide, like the pyrokinin FSPRLamide,

478 are almost certainly fragments of larger sNPF isoforms. Specifically, we propose that

479 SMPSLRLRFamide and PSLRLRFamide are both derived from the predicted full-length peptide

480 DMGWQVAQRSMPSLRLRFamide, while PSMRLRFamide is a fragment derived from

481 APPSMRLRFamide. Clearly as additional full-length preprohormones are identified from $C$.

482 borealis it will be interesting to see what light they may shed on the peptides identified

483 previously via mass spectral and other means, and how many of them can be confirmed as likely

484 full-length mature bioactive molecules and how many are questionable in this regard.

485

\subsection{Summary}

487 In silico transcriptome mining is a powerful means to identify and characterize crustacean 488 neuropeptides, and here it was used to expand the peptidome of the crab C. borealis. In total, 489200 distinct mature peptides were predicted for this species, 159 of them being new discoveries

490 for this important biomedical model. The peptides predicted here included isoforms from known 491 C. borealis peptide groups, i.e., AST-A, AST-B, AST-C, CCAP, CHH, CPRP, FLP,

492 HIGSLYRamide, leucokinin, PDH, pyrokinin, RPCH, sNPF and SIFamide, as well as those from 493 peptide families previously unknown in this species, i.e., CCHamide, DH31, DH44,

494 GSEFLamide, ILP, intocin and neuroparsin. The new discoveries described in our study double 495 the neuropeptidome now known for $C$. borealis, and, in several cases, clarify the nature of 496 peptides identified previously via mass spectrometry.

\section{Acknowledgements}

499 Financial support was provided by National Science Foundation grant IOS-1353023 (to 
500 AEC), the Cades Foundation of Honolulu, Hawaii (to AEC), and University of Hawaii's

501 Undergraduate Research Opportunities Program (to MGP).

502

503 References

504 Bao, C., Yang, Y., Huang, H., Ye, H., 2015. Neuropeptides in the cerebral ganglia of the mud

505 crab, Scylla paramamosain: transcriptomic analysis and expression profiles during

506 vitellogenesis. Sci. Rep. 5, 17055.

507

508 Blitz, D.M., Nusbaum, M.P., 2011. Neural circuit flexibility in a small sensorimotor system.

509 Curr. Opin. Neurobiol. 21, 544-552.

510

511 Böcking, D., Dircksen, H., Keller, R., 2002. The crustacean neuropeptide of the CHH/MIH/GIH

512 family: structures and biological activities. In: The Crustacean Nervous System. K Wiese (Ed.).

513 Springer, Heidelberg. pp. 84-97.

514

515 Christie, A.E., 2008a. Neuropeptide discovery in Ixodoidea: an in silico investigation using

516 publicly accessible expressed sequence tags. Gen. Comp. Endocrinol. 157, 174-185.

518 Christie, A.E., 2008b. In silico analyses of peptide paracrines/hormones in Aphidoidea. Gen.

519 Comp. Endocrinol. 159, 67-79.

520

521 Christie, A.E., 2011. Crustacean neuroendocrine systems and their signaling agents. Cell Tissue 522 Res. 345, 41-67. 
524 Christie, A.E., 2014a. Prediction of the first neuropeptides from a member of the Remipedia

525 (Arthropoda, Crustacea). Gen. Comp. Endocrinol. 201, 74-86.

526

527 Christie, A.E., 2014b. Prediction of the peptidomes of Tigriopus californicus and

528 Lepeophtheirus salmonis (Copepoda, Crustacea). Gen. Comp. Endocrinol. 201, 87-106.

529

530 Christie, A.E., 2014c. Peptide discovery in the ectoparasitic crustacean Argulus siamensis:

531 identification of the first neuropeptides from a member of the Branchiura. Gen. Comp.

532 Endocrinol. 204, 114-125.

533

534 Christie, A.E., 2014d. In silico characterization of the peptidome of the sea louse Caligus

535 rogercresseyi (Crustacea, Copepoda). Gen. Comp. Endocrinol. 204, 248-260.

536

537 Christie, A.E., 2014e. Identification of the first neuropeptides from the Amphipoda (Arthropoda,

538 Crustacea). Gen. Comp. Endocrinol. 206, 96-110.

539

540 Christie, A.E., 2014f. Expansion of the Litopenaeus vannamei and Penaeus monodon

541 peptidomes using transcriptome shotgun assembly sequence data. Gen. Comp. Endocrinol. 206, $542 \quad 235-254$. 
544 Christie, A.E., 2015a. Neuropeptide discovery in Eucyclops serrulatus (Crustacea, Copepoda): in

545 silico prediction of the first peptidome for a member of the Cyclopoida. Gen. Comp. Endocrinol.

$546 \quad 211,92-105$.

548 Christie, A.E., 2015b. In silico characterization of the neuropeptidome of the Western black

549 widow spider Latrodectus hesperus. Gen. Comp. Endocrinol. 210, 63-80.

550

551 Christie, A.E., 2015c. Neuropeptide discovery in Symphylella vulgaris (Myriapoda, Symphyla):

552 in silico prediction of the first myriapod peptidome. Gen. Comp. Endocrinol. 223, 73-86.

554 Christie, A.E., 2015d. In silico prediction of a neuropeptidome for the eusocial insect

555 Mastotermes darwiniensis. Gen. Comp. Endocrinol. 224, 69-83.

557 Christie, A.E., 2016a. Prediction of Scylla olivacea (Crustacea; Brachyura) peptide hormones 558 using publicly accessible transcriptome shotgun assembly (TSA) sequences. Gen. Comp.

559 Endocrinol. 230-23, 1-16.

561 Christie, A.E., 2016b. Expansion of the neuropeptidome of the globally invasive marine crab

562 Carcinus maenas. Gen. Comp. Endocrinol. 235, 150-169.

564 Christie, A.E., Cashman, C.R., Brennan, H.R., Ma, M., Sousa, G.L., Li, L., Stemmler, E.A., 565 Dickinson, P.S., 2008a. Identification of putative crustacean neuropeptides using in silico 566 analyses of publicly accessible expressed sequence tags. Gen. Comp. Endocrinol. 156, $246-264$. 
568 Christie, A.E., Cashman, C.R., Stevens, J.S., Smith, C.M., Beale, K.M., Stemmler, E.A.,

569 Greenwood, S.J., Towle, D.W., Dickinson, P.S., 2008b. Identification and cardiotropic actions

570 of brain/gut-derived tachykinin-related peptides (TRPs) from the American lobster Homarus

571 americanus. Peptides 29, 1909-1918.

572

573 Christie, A.E., Chapline, M.C., Jackson, J.M., Dowda, J.K., Hartline, N., Malecha, S.R., Lenz,

574 P.H., 2011d. Identification, tissue distribution and orexigenic activity of neuropeptide F (NPF)

575 in penaeid shrimp. J. Exp. Biol. 214, 1386-1396.

576

577 Christie, A.E., Chi, M., 2015a. Prediction of the neuropeptidomes of members of the Astacidea

578 (Crustacea, Decapoda) using publicly accessible transcriptome shotgun assembly (TSA)

579 sequence data. Gen. Comp Endocrinol. 224, 38-60.

580

581 Christie, A.E., Chi, M., 2015b. Neuropeptide discovery in the Araneae (Arthropoda, Chelicerata, 582 Arachnida): elucidation of true spider peptidomes using that of the Western black widow as a 583 reference. Gen. Comp. Endocrinol. 213, 90-109.

585 Christie, A.E., Chi, M., 2015c. Identification of the first neuropeptides from the enigmatic 586 hexapod order Protura. Gen. Comp. Endocrinol. 224, 18-37.

588 Christie, A.E., Chi, M., Lameyer, T.J., Pascual, M.G., Shea, D.N., Stanhope, M.E., Schulz, D.J., 589 Dickinson, P.S., 2015. Neuropeptidergic signaling in the American lobster Homarus 
americanus: new insights from high-throughput nucleotide sequencing. PLoS ONE. 10,

$591 \quad \mathrm{e} 0145964$.

592

593 Christie, A.E., Cieslak, M.C., Roncalli, V., Lenz, P.H., Major, K.M., Poynton, H.C., 2016.

594 Prediction of Hyalella azteca (Crustacea; Amphipoda) peptides using a de novo transcriptome 595 assembly. PLoS ONE. Submitted.

597 Christie, A.E., Durkin, C.S., Hartline, N., Ohno, P., Lenz, P.H., 2010b. Bioinformatic analyses 598 of the publicly accessible crustacean expressed sequence tags (ESTs) reveal numerous novel 599 neuropeptide-encoding precursor proteins, including ones from members of several little studied 600 taxa. Gen. Comp. Endocrinol. 167, 164-178.

601

602 Christie, A.E., Lundquist, C.T., Nässel, D.R., Nusbaum, M.P., 1997. Two novel tachykinin603 related peptides from the nervous system of the crab Cancer borealis. J. Exp. Biol. 200:22796042294.

605

606 Christie, A.E., McCoole, M.D., Harmon, S.M., Baer, K.N., Lenz, P.H., 2011c. Genomic 607 analyses of the Daphnia pulex peptidome. Gen. Comp. Endocrinol. 171, 131-150.

608

609 Christie, A.E., Nolan, D.H., Garcia, Z.A., McCoole, M.D., Harmon, S.M., Congdon-Jones, B., 610 Ohno, P., Hartline, N., Congdon, C.B., Baer, K.N., Lenz, P.H., 2011b. Bioinformatic prediction 611 of arthropod/nematode-like peptides in non-arthropod, non-nematode members of the 612 Ecdysozoa. Gen. Comp. Endocrinol. 170, 480-486. 
614 Christie, A.E., Nolan, D.H., Ohno, P., Hartline, N., Lenz, P.H., 2011a. Identification of

615 chelicerate neuropeptides using bioinformatics of publicly accessible expressed sequence tags.

616 Gen. Comp. Endocrinol. 170, 144-155.

617

618 Christie, A.E., Roncalli, V., Wu, L.S., Ganote, C.L., Doak, T., Lenz, P.H., 2013. Peptidergic

619 signaling in Calanus finmarchicus (Crustacea, Copepoda): in silico identification of putative

620 peptide hormones and their receptors using a de novo assembled transcriptome. Gen. Comp.

621 Endocrinol. 187, 117-135.

622

623 Christie, A.E., Stemmler, E.A., Dickinson, P.S., 2010a. Crustacean neuropeptides. Cell. Mol.

624 Life Sci. 67, 4135-4169.

625

626 Christie, A.E., Stevens, J.S., Bowers, M.R., Chapline, M.C., Jensen, D.A., Schegg, K.M.,

627 Goldwaser, J., Kwiatkowski, M.A., Pleasant, T.K. Jr., Shoenfeld, L., Tempest, L.K., Williams,

628 C.R., Wiwatpanit, T., Smith, C.M., Beale, K.M., Towle, D.W., Schooley, D.A., Dickinson, P.S.,

629 2010c. Identification of a calcitonin-like diuretic hormone that functions as an intrinsic

630 modulator of the American lobster, Homarus americanus, cardiac neuromuscular system. J.

631 Exp. Biol. 213, 118-127.

632

633 Chung, J.S., Wilcockson, D.C., Zmora, N., Zohar, Y., Dircksen, H., Webster, S.G., 2006.

634 Identification and developmental expression of mRNAs encoding crustacean cardioactive

635 peptide (CCAP) in decapod crustaceans. J. Exp. Biol. 209, 3862-3872. 
637 Cooke, I.M., 2002. Reliable, responsive pacemaking and pattern generation with minimal cell 638 numbers: the crustacean cardiac ganglion. Biol. Bull. 202, 108-136.

640 Cruz-Bermúdez, N.D., Fu, Q., Kutz-Naber, K.K., Christie, A.E., Li, L., Marder, E., 2006. Mass

641 spectrometric characterization and physiological actions of GAHKNYLRFamide, a novel

642 FMRFamide-like peptide from crabs of the genus Cancer. J. Neurochem. 97, 784-799.

644 Dickinson, P.S., Stemmler, E.A., Barton, E.E., Cashman, C.R., Gardner, N.P., Rus, S., Brennan, 645 H.R., McClintock, T.S., Christie, A.E., 2009b. Molecular, mass spectral, and physiological 646 analyses of orcokinins and orcokinin precursor-related peptides in the lobster Homarus 647 americanus and the crayfish Procambarus clarkii. Peptides 30, 297-317.

649 Dickinson, P.S., Stemmler, E.A., Cashman, C.R., Brennan, H.R., Dennison, B., Huber, K.E., 650 Peguero, B., Rabacal, W., Goiney, C.C., Smith, C.M., Towle, D.W., Christie, A.E., 2008.

651 SIFamide peptides in clawed lobsters and freshwater crayfish (Crustacea, Decapoda, Astacidea): 652 a combined molecular, mass spectrometric and electrophysiological investigation. Gen. Comp. 653 Endocrinol. 156, 347-360.

655 Dickinson, P.S., Stevens, J.S., Rus, S., Brennan, H.R., Goiney, C.C., Smith, C.M., Li, L., Towle, 656 D.W., Christie, A.E., 2007. Identification and cardiotropic actions of sulfakinin peptides in the 657 American lobster Homarus americanus. J. Exp. Biol. 210, 2278-2289. 
659 Dickinson, P.S., Wiwatpanit, T., Gabranski, E.R., Ackerman, R.J., Stevens, J.S., Cashman, C.R.,

660 Stemmler, E.A., Christie, A.E., 2009a. Identification of SYWKQCAFNAVSCFamide: a broadly

661 conserved crustacean C-type allatostatin-like peptide with both neuromodulatory and

662 cardioactive properties. J. Exp. Biol. 212, 1140-1152.

663

664 Dircksen, H., Neupert, S., Predel, R., Verleyen, P., Huybrechts, J., Strauss, J., Hauser, F.,

665 Stafflinger, E., Schneider, M., Pauwels, K., Schoofs, L., Grimmelikhuijzen, C.J., 2011.

666 Genomics, transcriptomics, and peptidomics of Daphnia pulex neuropeptides and protein

667 hormones. J. Proteome Res. 10, 4478-4504.

668

669 Fénelon, V., Le Feuvre, Y., Bem, T., Meyrand, P., 2003. Maturation of rhythmic neural

670 network: role of central modulatory inputs. J. Physiol. Paris 97, 59-68.

672 Ferrè, F., Clote, P., 2005. DiANNA: a web server for disulfide connectivity prediction. Nucleic

673 Acids Res. 33,W230-W232.

674

675 Fu, Q., Goy, M.F., Li, L., 2005a. Identification of neuropeptides from the decapod crustacean

676 sinus glands using nanoscale liquid chromatography tandem mass spectrometry. Biochem.

677 Biophys. Res. Commun. 337, 765-778.

678

679 Fu, Q., Kutz, K.K., Schmidt, J.J., Hsu, Y.W., Messinger, D.I., Cain, S.D., de la Iglesia, H.O.,

680 Christie, A.E., Li, L., 2005b. Hormone complement of the Cancer productus sinus gland and 
681 pericardial organ: an anatomical and mass spectrometric investigation. J. Comp. Neurol. 493, $682 \quad 607-626$.

684 Fu, Q., Tang, L.S., Marder, E., Li, L., 2007. Mass spectrometric characterization and 685 physiological actions of VPNDWAHFRGSWamide, a novel B type allatostatin in the crab, 686 Cancer borealis. J. Neurochem. 101, 1099-1107.

688 Gard, A.L., Lenz, P.H., Shaw, J.R., Christie, A.E., 2009. Identification of putative peptide 689 paracrines/hormones in the water flea Daphnia pulex (Crustacea; Branchiopoda; Cladocera) 690 using transcriptomics and immunohistochemistry. Gen. Comp. Endocrinol. 160, 271-287.

692 Hansen, K.K., Hauser, F., Williamson, M., Weber, S.B., Grimmelikhuijzen, C.J., 2011. The 693 Drosophila genes CG14593 and CG30106 code for G-protein-coupled receptors specifically 694 activated by the neuropeptides CCHamide-1 and CCHamide-2. Biochem. Biophys. Res.

695 Commun. 404, 184-189.

697 Hooper, S.L., DiCaprio, R.A., 2004. Crustacean motor pattern generator networks.

698 Neurosignals 13, 50-69.

699

700 Hsu, Y.W., Stemmler, E.A., Messinger, D.I., Dickinson, P.S., Christie, A.E., de la Iglesia, H.O..

701 2008b. Cloning and differential expression of two $\beta$-pigment-dispersing hormone $(\beta-\mathrm{PDH})$

702 isoforms in the crab Cancer productus: evidence for authentic $\beta$-PDH as a local neurotransmitter 703 and $\beta$-PDH II as a humoral factor. J. Comp. Neurol. 508, 197-211. 
705 Hsu, Y.W., Weller, J.R., Christie, A.E., de la Iglesia, H.O., 2008a. Molecular cloning of four

706 cDNAs encoding prepro-crustacean hyperglycemic hormone $(\mathrm{CHH})$ from the eyestalk of the red

707 rock crab Cancer productus: identification of two genetically encoded $\mathrm{CHH}$ isoforms and two

708 putative post-translationally derived CHH variants. Gen. Comp. Endocrinol. 155, 517-525.

709

710 Huybrechts, J., Nusbaum, M.P., Bosch, L.V., Baggerman, G., De Loof, A., Schoofs, L., 2003.

711 Neuropeptidomic analysis of the brain and thoracic ganglion from the Jonah crab, Cancer

712 borealis. Biochem. Biophys. Res. Commun. 308, 535-544.

713

714 Katoh, K., Standley, D.M., 2013. MAFFT multiple sequence alignment software version 7:

715 improvements in performance and usability. Mol. Biol. Evol. 30, 772-780.

716

717 Li, L., Kelley, W.P., Billimoria, C.P., Christie, A.E., Pulver, S.R., Sweedler, J.V., Marder, E.,

718 2003. Mass spectrometric investigation of the neuropeptide complement and release in the

719 pericardial organs of the crab, Cancer borealis. J. Neurochem. 87, 642-656.

720

721 Li, L., Pulver, S.R., Kelley, W.P., Thirumalai, V., Sweedler, J.V., Marder, E., 2002. Orcokinin

722 peptides in developing and adult crustacean stomatogastric nervous systems and pericardial

723 organs. J. Comp. Neurol. 444, 227-244. 
725 Linck, B., Klein, J.M., Mangerich, S., Keller, R., Weidemann, W.M., 1993. Molecular cloning

726 of crustacean red pigment concentrating hormone precursor. Biochem. Biophys. Res. Commun.

$727195,807-813$.

728

729 Lu, W., Wainwright, G., Webster, S.G., Rees, H.H., Turner, P.C., 2000. Clustering of

730 mandibular organ-inhibiting hormone and moult-inhibiting hormone genes in the crab, Cancer

731 pagurus, and implications for regulation of expression. Gene 253, 197-207.

732

733 Ma, M., Bors, E.K., Dickinson, E.S., Kwiatkowski, M.A., Sousa, G.L., Henry, R.P., Smith,

734 C.M., Towle, D.W., Christie, A.E., Li, L., 2009e. Characterization of the Carcinus maenas

735 neuropeptidome by mass spectrometry and functional genomics. Gen. Comp. Endocrinol. 161, $736 \quad 320-334$.

737

738 Ma, M., Chen, R., Ge, Y., He, H., Marshall, A.G., Li, L., 2009a. Combining bottom-up and top739 down mass spectrometric strategies for de novo sequencing of the crustacean hyperglycemic

740 hormone from Cancer borealis. Anal. Chem. 81, 240-247.

741

742 Ma, M., Gard, A.L., Xiang, F., Wang, J., Davoodian, N., Lenz, P.H., Malecha, S.R., Christie, 743 A.E., Li, L., 2010. Combining in silico transcriptome mining and biological mass spectrometry 744 for neuropeptide discovery in the Pacific white shrimp Litopenaeus vannamei. Peptides 31, 27 74543. 
747 Ma, M., Sturm, R.M., Kutz-Naber, K.K., Fu, Q., Li, L., 2009d. Immunoaffinity-based mass

748 spectrometric characterization of the FMRFamide-related peptide family in the pericardial organ

749 of Cancer borealis. Biochem. Biophys. Res. Commun. 390, 325-330.

750

751 Ma, M., Szabo, T.M., Jia, C., Marder, E., Li, L., 2009c. Mass spectrometric characterization and

752 physiological actions of novel crustacean C-type allatostatins. Peptides 30, 1660-1668.

753

754 Ma, M., Wang, J., Chen, R., Li, L., 2009b. Expanding the Crustacean neuropeptidome using a

755 multifaceted mass spectrometric approach. J. Proteome Res. 8, 2426-2437.

756

757 Marder, E., Bucher, D., 2007. Understanding circuit dynamics using the stomatogastric nervous 758 system of lobsters and crabs. Annu. Rev. Physiol. 69, 291-316.

759

760 Marder, E., Christie, A.E., Kilman, V.L., 1995. Functional organization of cotransmission

761 systems: lessons from small nervous systems. Invert. Neurosci. 1; 105-112.

762

763 Marder, E., Hooper, S.L., Siwicki, K.K., 1986. Modulatory action and distribution of the

764 neuropeptide proctolin in the crustacean stomatogastric nervous system. J. Comp. Neurol. 243, $765 \quad 454-467$.

766

767 Monigatti, F., Gasteiger, E., Bairoch, A., Jung, E., 2002. The Sulfinator: predicting tyrosine 768 sulfation sites in protein sequences. Bioinformatics 18, 769-770. 
770 Northcutt, A.J., Lett, K.M., Garcia, V.B., Diester, C.M., Lane, B.J., Marder, E., Schulz, D.J.,

771 2016. Deep sequencing of transcriptomes from the nervous systems of two decapod crustaceans

772 to characterize genes important for neural circuit function and modulation. BMC Genomics

773 Submitted.

774

775 Nusbaum, M.P., Blitz, D.M., Swensen, A.M., Wood, D., Marder, E., 2001. The roles of co-

776 transmission in neural network modulation. Trends Neurosci. 24, 146-154.

777

778 Petersen, T.N., Brunak, S., von Heijne, G., Nielsen, H., 2011. SignalP 4.0: discriminating signal

779 peptides from transmembrane regions. Nat. Methods 8,785-786.

780

781 Rafaeli, A., 2009. Pheromone biosynthesis activating neuropeptide (PBAN): regulatory role and 782 mode of action. Gen. Comp. Endocrinol. 162, 69-78.

783

784 Selverston, A.I., 2005. A neural infrastructure for rhythmic motor patterns. Cell. Mol.

785 Neurobiol. 25, 223-244.

786

787 Selverston, A.I., Ayers, J., 2006. Oscillations and oscillatory behavior in small neural circuits.

788 Biol. Cybern. 95, 537-554.

789

790 Selverston, A., Elson, R., Rabinovich, M., Huerta, R., Abarbanel, H., 1998. Basic principles for

791 generating motor output in the stomatogastric ganglion. Ann N.Y. Acad. Sci. 860, 35-50.

792 
793 Skiebe, P., 2001. Neuropeptides are ubiquitous chemical mediators: Using the stomatogastric

794 nervous system as a model system. J. Exp. Biol. 204, 2035-2048.

795

796 Stafflinger, E., Hansen, K.K., Hauser, F., Schneider, M., Cazzamali, G., Williamson, M.,

797 Grimmelikhuijzen, C.J., 2008. Cloning and identification of an oxytocin/vasopressin-like

798 receptor and its ligand from insects. Proc. Natl. Acad. Sci. USA. 105, 3262-3267.

799

800 Stein, W., 2009. Modulation of stomatogastric rhythms. J. Comp. Physiol. A Neuroethol. Sens.

801 Neural Behav. Physiol. 195, 989-1009.

802

803 Stemmler, E.A., Bruns, E.A., Cashman, C.R., Dickinson, P.S., Christie, A.E., 2010. Molecular

804 and mass spectral identification of the broadly conserved decapod crustacean neuropeptide

805 pQIRYHQCYFNPISCF: the first PISCF-allatostatin (Manduca sexta- or C-type allatostatin)

806 from a non-insect. Gen. Comp. Endocrinol. 165, 1-10.

807

808 Stemmler, E.A., Bruns, E.A., Gardner, N.P., Dickinson, P.S., Christie, A.E., 2007a. Mass

809 spectrometric identification of pEGFYSQRYamide: a crustacean peptide hormone possessing a

810 vertebrate neuropeptide Y (NPY)-like carboxy-terminus. Gen. Comp. Endocrinol. 152, 1-7.

811

812 Stemmler, E.A., Cashman, C.R., Messinger, D.I., Gardner, N.P., Dickinson, P.S., Christie, A.E.,

813 2007c. High-mass-resolution direct-tissue MALDI-FTMS reveals broad conservation of three

814 neuropeptides (APSGFLGMRamide, GYRKPPFNGSIFamide and pQDLDHVFLRFamide)

815 across members of seven decapod crustaean infraorders. Peptides 28, 2104-2115. 
817 Stemmler, E.A., Peguero, B., Bruns, E.A., Dickinson, P.S., Christie, A.E., 2007b. Identification,

818 physiological actions, and distribution of TPSGFLGMRamide: a novel tachykinin-related

819 peptide from the midgut and stomatogastric nervous system of Cancer crabs. J. Neurochem.

$820101,1351-1366$.

822 Stemmler, E.A., Provencher, H.L., Guiney, M.E., Gardner, N.P., Dickinson, P.S., 2005. Matrix-

823 assisted laser desorption/ionization fourier transform mass spectrometry for the identification of

824 orcokinin neuropeptides in crustaceans using metastable decay and sustained off-resonance

825 irradiation. Anal. Chem. 77, 3594-3606.

826

827 Stevens, J.S., Cashman, C.R., Smith, C.M., Beale, K.M., Towle, D.W., Christie, A.E.,

828 Dickinson, P.S., 2009. The peptide hormone pQDLDHVFLRFamide (crustacean

829 myosuppressin) modulates the Homarus americanus cardiac neuromuscular system at multiple

830 sites. J. Exp. Biol. 212, 3961-3976.

832 Suwansa-Ard, S., Thongbuakaew, T., Wang, T., Zhao, M., Elizur, A., Hanna, P.J., Sretarugsa, P.,

833 Cummins, S.F., Sobhon, P., 2015. In silico neuropeptidome of female Macrobrachium

834 rosenbergii based on transcriptome and peptide mining of eyestalk, central nervous system and

835 ovary. PLoS One 10, e0123848.

837 Szabo, T.M., Chen, R., Goeritz, M.L., Maloney, R.T., Tang, L.S., Li, L., Marder, E., 2011.

838 Distribution and physiological effects of B-type allatostatins (myoinhibitory peptides, MIPs) in 
839 the stomatogastric nervous system of the crab Cancer borealis. J. Comp. Neurol. 519, 2658-

$840 \quad 2676$.

841

842 Tang C, Lu W, Wainwright G, Webster SG, Rees HH, Turner PC.Molecular characterization and

843 expression of mandibular organ-inhibiting hormone, a recently discovered neuropeptide involved

844 in the regulation of growth and reproduction in the crab Cancer pagurus. Biochem. J. 343, 355-

845360.

846

847 Toullec, J.Y., Corre, E., Bernay, B., Thorne, M.A., Cascella, K., Ollivaux, C., Henry, J., Clark,

848 M.S., 2013. Transcriptome and peptidome characterisation of the main neuropeptides and

849 peptidic hormones of a euphausiid: the Ice Krill, Euphausia crystallorophias. PLoS One. 8, $850 \quad$ e71609.

851

852 Veenstra, J.A., 2000. Mono- and dibasic proteolytic cleavage sites in insect neuroendocrine 853 peptide precursors. Arch. Insect. Biochem. Physiol. 43, 49-63.

855 Veenstra, J.A., 2015. The power of next-generation sequencing as illustrated by the 856 neuropeptidome of the crayfish Procambarus clarkii. Gen. Comp. Endocrinol. 224, 84-95. 857

858 Ventura, T., Cummins, S.F., Fitzgibbon, Q., Battaglene, S., Elizur, A., 2014. Analysis of the 859 central nervous system transcriptome of the eastern rock lobster Sagmariasus verreauxi reveals 860 its putative neuropeptidome. PLoS One 9, e97323. 
862 Weimann, J.M., Marder, E., Evans, B., Calabrese, R.L., 1993. The effects of SDRNFLRFamide

863 and TNRNFLRFamide on the motor patterns of the stomatogastric ganglion of the crab Cancer

864 borealis. J. Exp. Biol. 181:1-26.

865

866 Wilcockson, D.C., Webster, S.G., 2008. Identification and developmental expression of mRNAs

867 encoding putative insect cuticle hardening hormone, bursicon in the green shore crab Carcinus

868 maenas. Gen Comp Endocrinol. 2008 Mar 1;156(1):113-25.

869

870 Yan, X.C., Chen, Z.F., Sun, J., Matsumura, K., Wu, R.S., Qian, P.Y., 2012. Transcriptomic

871 analysis of neuropeptides and peptide hormones in the barnacle Balanus amphitrite: evidence of

872 roles in larval settlement. PLoS One 7, e46513.

873

874 Yasuda-Kamatani, Y., Yasuda, A., 2006. Characteristic expression patterns of allatostatin-like

875 peptide, FMRFamide-related peptide, orcokinin, tachykinin-related peptide, and SIFamide in the

876 olfactory system of crayfish Procambarus clarkii. J. Comp. Neurol. 496, 135-147.

$878 \quad$ Figure legends

879 Figure 1. Three examples of the in silico workflow used for the prediction of putative mature

880 Cancer borealis peptide structures. (A) The predicted processing scheme for prepro-allatostatin

881 C (AST-C) I. The structure of the putative mature AST-C isoform is shown in red, with those of

882 six putative mature linker/precursor-related peptides shown in blue. In the AST-C isoform, "pQ"

883 indicates pyroglutamic acid, while the presence of a disulfide bridge between the two cysteine

884 residues in indicates by an inverted red bracket. (B) The predicted processing scheme for 
885 prepro-diuretic hormone 31 (DH31). The structure of the putative mature DH31 isoform is

886 shown in red, with those of three putative mature linker/precursor-related peptides shown in

887 blue. "Y ${ }_{(\mathrm{SO} 3 \mathrm{H})}$ " indicates the presence of a sulfated tyrosine residue in one of the

888 linker/precursor-related peptides. (C) The predicted processing scheme for prepro-short

889 neuropeptide F (sNPF). The structures of three putative mature sNPF isoforms are shown in red,

890 with those of three putative mature linker/precursor-related peptides shown in blue. "Y(SO3H)"

891 indicates the presence of a sulfated tyrosine residue in one of the linker/precursor-related

892 peptides.

893

894 Figure 2. Putative Cancer borealis pre/preprohormones deduced from transcriptome shotgun

895 assembly sequence data. (A) Three internal fragments from prepro-allatostatin A. (B1) The

896 amino (N)-terminus of prepro-allatostatin B I. (B2) The carboxyl (C)-terminus of prepro-

897 allatostatin B II. (C) The C-terminus of prepro-allatostatin C II. (D) Prepro-CCHamide. (E)

898 Prepro-crustacean cardioactive peptide. (F) Prepro-crustacean hyperglycemic hormone. (G)

899 Prepro-diuretic hormone 44. (H) The C-terminus of prepro-FMRFamide-like peptide. (I) The

900 N-terminus of prepro-GSEFLamide. (J) The N-terminus of prepro-HIGSLYRamide. (K)

901 Prepro-insulin-like peptide. (L). Prepro-intocin. (M) The C-terminus of prepro-leucokinin.

902 (N1). Pre-neuroparsin I. (N2) Pre-neuroparsin II. (N3) Pre-neuroparsin III. (N4) Pre-

903 neuroparsin IV. (O) Prepro-pigment dispersing hormone. (P) Prepro-pyrokinin. (Q) Prepro-red

904 pigment concentrating hormone. (R) Prepro-SIFamide. In this figure, signal peptides are shown

905 in gray, while all mono/dibasic cleavage loci are shown in black. For each sequence, the

906 isoform(s) of the peptide for which the precursor is named is/are shown in red, with all 
907 linker/precursor related peptides shown in blue. The "+" symbol indicate the presence of

908 additional, unknown, amino acid residues at the $\mathrm{N}$ - and/or C-termini of the protein in question. 
Table 1. Cancer borealis (Canbo) peptide precursor-encoding transcripts and their deduced proteins

\begin{tabular}{|c|c|c|c|c|c|c|c|}
\hline \multirow[b]{2}{*}{ Peptide family } & \multicolumn{4}{|l|}{ Transcript } & \multicolumn{3}{|l|}{ Deduced protein } \\
\hline & Accession No. & Length* & BLAST score & E-value & Name & Length $\dagger$ & Type \\
\hline \multicolumn{8}{|l|}{$\mathrm{ACP}$} \\
\hline AST-A & GEFB01005316 & 2580 & 186 & $4 \mathrm{e}-76$ & Canbo-prepro-AST-A & 709\# & I \\
\hline \multirow[t]{2}{*}{ AST-B } & GEFB01009802 & 766 & 267 & $2 \mathrm{e}-87$ & Canbo-prepro-AST-B I & 195 & $\mathrm{~N}$ \\
\hline & GEFB01004713 & 869 & 35.8 & 4.3 & Canbo-prepro-AST-B II & 43 & $\mathrm{C}$ \\
\hline \multirow[t]{2}{*}{ AST-C } & GEFB01008004 & 1331 & 171 & $1 \mathrm{e}-48$ & Canbo-prepro-AST-C I & 150 & $\mathrm{~F}$ \\
\hline & GEFB01014354 & 1188 & 110 & $6 e-27$ & Canbo-prepro-AST-C II & 56 & $\mathrm{C}$ \\
\hline \multicolumn{8}{|l|}{ Allatotropin } \\
\hline \multicolumn{8}{|l|}{ Bursicon $\alpha$} \\
\hline \multicolumn{8}{|l|}{ Bursicon $\beta$} \\
\hline CCHamide & GEFB01009198 & 1092 & 33.1 & 8.8 & Canbo-prepro-CCHamide & 195 & $\mathrm{~F}$ \\
\hline \multicolumn{8}{|l|}{ Corazonin } \\
\hline CCAP & GEFB01016342 & 574 & 204 & $3 e-64$ & Canbo-prepro-CCAP & 142 & F \\
\hline $\mathrm{CHH} / \mathrm{MIH}$ & GEFB01007482 & 626 & 57.8 & $2 \mathrm{e}-08$ & Canbo-prepro-CHH & 130 & $\mathrm{~F}$ \\
\hline \multicolumn{8}{|l|}{ DENamide } \\
\hline DH31 & GEFB01004916 & 1495 & 154 & $6 e-42$ & Canbo-prepro-DH31 & 146 & F \\
\hline DH44 & GEFB01005116 & 2427 & 124 & $6 e-31$ & Canbo-prepro-DH44 & 327 & $\mathrm{~F}$ \\
\hline \multicolumn{8}{|l|}{ DXXRLamide } \\
\hline \multicolumn{8}{|l|}{ ETH } \\
\hline \multicolumn{8}{|l|}{ EH } \\
\hline FLP & GEFB01000266 & 2239 & 74.3 & $6 e-12$ & Canbo-prepro-FLP & 264 & $\mathrm{C}$ \\
\hline \multicolumn{8}{|l|}{ FXGGXamide } \\
\hline GSEFLamide & GEFB01024463 & 601 & 33.9 & 7.5 & Canbo-prepro-GSEFLamide & 182 & $\mathrm{~N}$ \\
\hline HIGSLYRamide & GEFB01004531 & 2587 & 275 & $4 \mathrm{e}-83$ & Canbo-prepro-HIGSLYRamide & 760 & $\mathrm{~N}$ \\
\hline ILP & GEFB01034529 & 804 & 111 & $8 \mathrm{e}-27$ & Canbo-prepro-ILP & 165 & $\mathrm{~F}$ \\
\hline Intocin & GEFB01036259 & 788 & 52.0 & $6 \mathrm{e}-07$ & Canbo-prepro-intocin & 157 & $\mathrm{~F}$ \\
\hline Leucokinin & GEFB01013465 & 1257 & 50.4 & $3 e-04$ & Canbo-prepro-leucokinin & 116 & $\mathrm{C}$ \\
\hline \multicolumn{8}{|l|}{ Myosuppressin } \\
\hline \multirow[t]{4}{*}{ Neuroparsin } & GEFB01000285 & 1990 & 122 & $9 \mathrm{e}-31$ & Canbo-pre-neuroparsin I & 101 & $\mathrm{~F}$ \\
\hline & GEFB01009505 & 2077 & 103 & $4 \mathrm{e}-24$ & Canbo-pre-neuroparsin II & 101 & $\mathrm{~F}$ \\
\hline & GEFB01037835 & 929 & 68.2 & $4 \mathrm{e}-12$ & Canbo-pre-neuroparsin III & 101 & $\mathrm{~F}$ \\
\hline & GEFB01000829 & 1964 & 68.2 & $1 \mathrm{e}-11$ & Canbo-pre-neuroparsin IV & 104 & $\mathrm{~F}$ \\
\hline \multicolumn{8}{|c|}{ 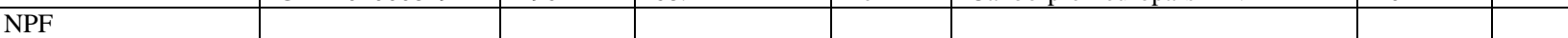 } \\
\hline \multicolumn{8}{|l|}{ Orcokinin } \\
\hline PDH & GEFB01009346 & 516 & 121 & $3 e-33$ & Canbo-prepro-PDH & 78 & $\bar{F}$ \\
\hline \multicolumn{8}{|l|}{ Proctolin } \\
\hline Pyrokinin & GEFB01006571 & 1612 & 217 & $3 e-65$ & Canbo-prepro-pyrokinin & 338 & F \\
\hline RPCH & GEFB01008309 & 1041 & 81.6 & $9 \mathrm{e}-17$ & Canbo-prepro-RPCH & 109 & $\mathrm{~F}$ \\
\hline \multicolumn{8}{|l|}{ RYamide } \\
\hline SNPF & GEFB01013717 & 1743 & 186 & $2 \mathrm{e}-53$ & Canbo-prepro-sNPF & 125 & $\mathrm{~F}$ \\
\hline SIFamide & GEFB01002741 & 5751 & 86.7 & $5 e-18$ & Canbo-prepro-SIFamide & 78 & $\mathrm{~F}$ \\
\hline \multicolumn{8}{|l|}{ Sulfakinin } \\
\hline TRP & & & & & & & \\
\hline
\end{tabular}

Peptide family abbreviations: ACP, adipokinetic hormone-corazonin-like peptide; AST-A, allatostatin A; AST-B, allatostatin B; AST-C, allatostatin C; CCAP, crustacean cardioactive peptide; $\mathrm{CHH} / \mathrm{MIH}$, crustacean hyperglycemic hormone/molt-inhibiting hormone; DH31, diuretic hormone 31; DH44, diuretic hormone 44; ETH, ecdysis-triggering hormone; EH, eclosion hormone; FLP, FMRFamide-like peptide; ILP, insulinlike peptide; NPF, neuropeptide F; PDH, pigment dispersing hormone; RPCH, red pigment concentrating hormone; sNPF, short neuropeptide F; TRP, tachykinin-related peptide.

Deduced protein type abbreviations: F, full-length; I, internal fragment protein; N, amino-terminal partial protein; C, carboxyl-terminal partial protein.

Query proteins: adipokinetic hormone-corazonin-like peptide, Scylla olivacea-prepro-ACP I (deduced from GDRN01070310; Christie, 2016a); allatostatin A, Carcinus maenas prepro-AST-A I(deduced from GBXE01122322; Christie, 2016b); allatostatin B; S. olivacea-prepro-AST-B I (deduced from GDRN01076322; Christie, 2016a); allatostatin C, C. maenas-prepro-AST-C I (deduced from GBXE01048780; Christie, 2016b), C. maenas-prepro-AST-C II (deduced from GBXE01097464; Christie, 2016b) and C. maenas-prepro-AST-C III (deduced from GBXE01075055; Christie, 2016b) ; allatotropin, Tigriopus californicus prepro-allatotropin (deduced from JW513825; Christie, 2014b); bursicon

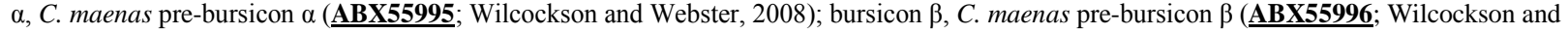
Webster, 2008); CCHamide, Procambarus clarkii prepro-CCHamide I (deduced from GBEV01004199; Christie and Chi, 2015a); corazonin, $S$. olivacea prepro-corazonin (deduced from GDRN01069484; Christie, 2016a); crustacean cardioactive peptide, C. maenas prepro-CCAP 
(ABB46291; Chung et al., 2006); crustacean hyperglycemic hormone/molt-inhibiting hormone, Cancer productus prepro-CHH I (ABQ41269;

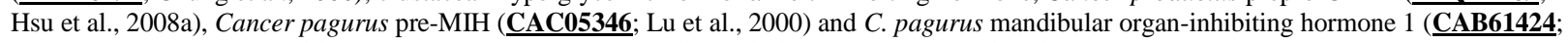
Tang et al., 1999); DENamide, Daphnia pulex prepro-DENamide (Dircksen et al., 2011); diuretic hormone 31, Homarus americanus prepro-

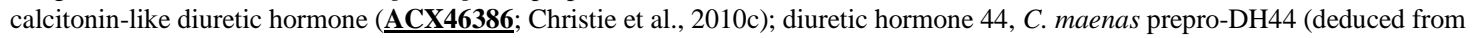
GBXE01028849; Christie, 2016b); DXXRLamide, T. californicus prepro-DXXRLamide Ia (deduced from JW528324; Christie, 2014b); ecdysistriggering hormone, D. pulex prepro-ETH (Dircksen et al., 2011); eclosion hormone (EH), S. olivacea pre-EH (deduced from GDRN01025034; Christie, 2016a); FMRFamide-like peptide; P. clarkii prepro-FLRFamide A (BAE06262; Yasuda-Kamatani and Yasuda, 2006); FXGGXamide, T. californicus prepro-FXGGXamide Ia (deduced from JV193177; Christie, 2014b); GSEFLamide, P. clarkii prepro-GSEFLamide (deduced from GBEV01013249; Christie and Chi, 2015a); HIGSLYRamide, C. maenas prepro-HIGSLYRamide (deduced from DV111329; Christie et al., 2008a); insulin-like peptide, H. americanus prepro-insulin-like peptide (Christie et al., 2015); intocin, S. olivacea prepro-intocin (deduced from GDRN01127322; Christie, 2016a); leucokinin, S. olivacea prepro-leucokinin (deduced from GDRN01058507; Christie, 2016a); myosuppressin, H. americanus prepro-myosuppressin ( $\underline{\mathbf{A C X 4 6 3 8 5}}$; Stevens et al., 2009); neuroparsin, S. olivacea pre-neuroparsin Ia (deduced from GDRN01069880; Christie, 2016a); neuropeptide F, Litopenaeus vannamei prepro-NPF I (AEC12204, Christie et al, 2011d); orcokinin, $H$. americanus prepro-orcokinin I ( $\underline{\mathbf{A C B 4 1 7 8 7}}$; Dickinson et al., 2009b); pigment dispersing hormone, $C$. productus prepro-PDH I (ABV68725; Hsu et al., 2008b); proctolin, C. maenas prepro-proctolin (deduced from GBXE01083406; Christie 2016b); pyrokinin, S. olivacea prepro-pyrokinin (deduced from GDRN01096339; Christie, 2016a); red pigment concentrating hormone, C. maenas prepro-RPCH ( $\underline{\mathbf{A A B 2 8 1 3 3}}$; Linck et al., 1993); RYamide, P. clarkii prepro-RYamide (deduced from GBEV01010112; Christie and Chi, 2015a); short neuropeptide F, S. olivacea preprosNPF (deduced from GDRN01012387; Christie, 2016a); SIFamide, H. americanus prepro-Val ${ }^{1}$-SIFamide (ABV21807; Dickinson et al., 2008); sulfakinin, H. americanus prepro-sulfakinin (ABQ95346; Dickinson et al., 2007); tachykinin-related peptide (TRP), H. americanus prepro-TRP (ACB41786; Christie et al., 2008b). 


\begin{tabular}{|c|c|}
\hline Peptide family & Peptide structure \\
\hline \multirow[t]{30}{*}{ AST-A } & +MGIAARTMISGLVRETPMPLGLENVLVLTPSGLERENHMAGPYSFGLa \\
\hline & PEPYAFGLa \\
\hline & PATDLYAFGLa \\
\hline & DPYAFGLa \\
\hline & PADLYEFGLa \\
\hline & GDPYAFGLa \\
\hline & PDMYAFGLa \\
\hline & SSGQYAFGLa \\
\hline & PSMYAFGLa \\
\hline & PDMYGFGLa \\
\hline & GSGQYAFGLa \\
\hline & AGQYSFGLa \\
\hline & SGSYSFGLa \\
\hline & GGAYSFGLa \\
\hline & DRPYSFGLa \\
\hline & HSPSYASSDFGLa \\
\hline & APQPYAFGLa \\
\hline & AGLYSYGLa \\
\hline & SDMYSFGLa \\
\hline & SGSYNFGLa \\
\hline & PRAYSFGLa \\
\hline & PRDYAFGLa \\
\hline & PKTYSFGLa \\
\hline & PQRAYSFGLa \\
\hline & LRAYSFGLa \\
\hline & PQRDYSFGLa \\
\hline & GYDSEDEDNQLFGFGLa \\
\hline & PRTYSFGLa \\
\hline & ALGVYGDSRQNYDFGLa \\
\hline & AGPYSFGLa \\
\hline \multirow[t]{19}{*}{ AST-A PRP } & SPSDVSDSYTLA \\
\hline & ETIEEDEDDHTKMAADNKALPVPPSSSSSSSSSS \\
\hline & +EEAAEIEDEYDQLGFa \\
\hline & SVRDVGSEEEDK \\
\hline & $+\mathrm{EV}$ \\
\hline & ISDEEEEEED \\
\hline & TDSQYDNYN \\
\hline & QEDVGFS \\
\hline & $\mathrm{DY}_{(\text {(ОозH })} \mathrm{DDSDVE}$ \\
\hline & DQDSDLE \\
\hline & DDDSDVE \\
\hline & EDDSDIE \\
\hline & EDDSDVE \\
\hline & ADEEDDEEEEEEEDEEEGLDVDVVEDLA \\
\hline & EPYGWSLLLWAWQERTLCI \\
\hline & AWKEASNRLI \\
\hline & IRAWQ \\
\hline & PLRFRAWQTTC \\
\hline & SL \\
\hline \multirow[t]{10}{*}{ AST-B } & AGWSSMRGAWa \\
\hline & NNNWSKFQGSWa \\
\hline & GNWNKFQGSWa \\
\hline & GGWNKFQGSWa \\
\hline & TSWGKFQGSWa \\
\hline & NNWSKFQGSWa \\
\hline & AGWSSLQ+ \\
\hline & +GTWa \\
\hline & SGKWSNLRGAWa \\
\hline & VPNDWAHFRGSWa \\
\hline \multirow[t]{5}{*}{ AST-B PRP } & QDEGSGLAGAQA \\
\hline & TPDDTPEHGLQVSED \\
\hline & GEEIQDAEE \\
\hline & ADDMTEEAALQAAED \\
\hline & GDEVASEDDFQDGED \\
\hline
\end{tabular}




\begin{tabular}{|c|c|}
\hline & QDDLIHLQDLED \\
\hline & TPDTLISA \\
\hline \multirow[t]{2}{*}{ AST-C } & PQIRYHQCYFNPISCF \\
\hline & SYWKQCAFNAVSCFa \\
\hline \multirow{7}{*}{ AST-C PRP } & $\bar{L} P A$ \\
\hline & VPDAPKEVSKGHEGGRLQ \\
\hline & AAASSASDTSEEELAALKDI ILARLAAELDDSWQDLPSF \\
\hline & DLLKGDMDEEEDDEGDEGS \\
\hline & EDV \\
\hline & MFAPLSGLPGNLRTI \\
\hline & +LEDDGTLDAALINYLFAKQLVQRLRTPSEVSREAQ \\
\hline CCHamide & HGPVKVGCLNYGHSCLGAHa \\
\hline \multirow[t]{4}{*}{ CCHamide PRP } & 1 \\
\hline & ALPAQVKPDAAPLEEEDDLLYYTTYEDDY $_{(\mathrm{SO} O 3 \mathrm{H})}$ GDHRA \\
\hline & SVDKTEE \\
\hline & ALPTRASVSCLLLFSRRC \\
\hline CCAP & PFCNAFTGCa \\
\hline \multirow[t]{5}{*}{ CCAP PRP } & RPVTL \\
\hline & DIDSLLERKI \\
\hline & SDPKLEGLASGSELNDNKNVLAEARLWEQLQSEMETMRLLAS \\
\hline & IDGRPTY \\
\hline & SLNHPQHDCTHSAQTIDHKVTCTQL \\
\hline $\mathrm{CHH}$ & 2 \\
\hline CPRP & GPVYPQHTASPVQSQALPGEAKQL \\
\hline DH31 & GLDMGLGRGFSGSQAAKHLMGIAAANYAGGPa \\
\hline \multirow[t]{3}{*}{ DH31 PRP } & SPINREPSRAVVEIDDPDY $_{\text {(МОзH) }}$ VLELLTRFSNS I I \\
\hline & AKELEKFVRSSSGA \\
\hline & ESEAATIDQHHDDHHLAVQQHSAAAAAAAPAGLSPHSS \\
\hline DH44 & SSGLSLSIDASMKVLREALYLEIARKKQRQQLQRAQHNKALLNTIa \\
\hline \multirow[t]{8}{*}{ DH44 PRP } & LSLEGVRGAHGPP \\
\hline & 3 \\
\hline & NPRYM \\
\hline & FTEYQPRNSAEANNNSNNRKA \\
\hline & DSRNS \\
\hline & SVTNNNTNNNNNNNSLTSSTSTGTSTTPNNNNNNNNKL_ANNHNSGMF \\
\hline & AWPHSFS \\
\hline & DVASQLVGVDQGVALQNARN \\
\hline \multirow[t]{9}{*}{ FLP } & GGRNFLRFa \\
\hline & NRNFLRFa \\
\hline & GAHKNYLRFa \\
\hline & GNRNFLRFa \\
\hline & SENRNFLRFa \\
\hline & AYNRSFLRFa \\
\hline & DRNFLRFa \\
\hline & APQRNFLRFa \\
\hline & +SSSEEDKHRFa \\
\hline \multirow[t]{6}{*}{ FLP PRP } & SEED \\
\hline & GDSSSVEDMDVLPETEDTIE \\
\hline & SDAEEFGLPGGPLAFDNNVQEDDLTDY $_{(\text {(Оон) }}$ PMEE \\
\hline & SVDRQLSEQKTRDAPVAPTATIHSPAKTQESHRS \\
\hline & AASPYNYVVLPSHGPAAWAQNFQPDQDDDLEEAVDGPDVA \\
\hline & SDEDDASDMMMMDPASYNRYV \\
\hline \multirow[t]{2}{*}{ GSEFLamide } & IGSEFLa \\
\hline & MGSEFLa \\
\hline \multirow[t]{8}{*}{ GSEFLamide PRP } & DEGVGEVA \\
\hline & GGGSSRDPML \\
\hline & YLLVAMAQPGPRYAAPQILSRGV \\
\hline & SPVVESPEVVESPEPGKTCEESGSCVTEEDHDHADDL \\
\hline & EQLSFTGQYNĒQEGSDGLQDEPD \\
\hline & VLGALSRSRLA \\
\hline & YLSLLMN \\
\hline & AVG+ \\
\hline \multirow[t]{4}{*}{ HIGSLYRamide } & HIGSLYRa \\
\hline & HIGSLYRS \\
\hline & HIGSLYRD \\
\hline & HYSSLLRa \\
\hline
\end{tabular}




\begin{tabular}{|c|c|}
\hline & HIGSLYLSED \\
\hline \multirow[t]{20}{*}{ HIGSLYRamide PRP } & QDAAAAPVASQQQEEQPARE \\
\hline & FLGSVLRQDGRLPIWGF \\
\hline & SFGVQQDSDSDHNDALTLPAASPVEGI PSQSPQTQALE \\
\hline & HLSSLARNNAYPKDLRE \\
\hline & YFASLLKSRAFGDDSKLI PHNAAGDSEPHLQ \\
\hline & FYASLLKSDSPPQTAYLNSMFYRQD \\
\hline & HYSSLLRNGPLPFIQD \\
\hline & HFGSLLKSPSYRAISIPa \\
\hline & $\begin{array}{l}\text { SPNAVEDPEDNPVRELEDIRDLSSGFDGDLDLHDRLVAAGVISPGLSVRGDTQDLEALLTAWYAAATSGQD } \\
\end{array}$ \\
\hline & DEDSLYQDLNED \\
\hline & EDNLY $_{(\text {(ОонH }}$ HDLSED \\
\hline & NEDNLLNLSED \\
\hline & DEDNSYYDLNED \\
\hline & DEDNLYYDLNED \\
\hline & DEDNLY $_{(\text {(SO3H) }}$ HELSED \\
\hline & DEDNMYQNLLED \\
\hline & DEDNFQGLSED \\
\hline & DEDNSQNLAED \\
\hline & DEDNSQNLSED \\
\hline & DEDNTNSLSED \\
\hline \multirow[t]{2}{*}{ ILP } & LCGWKLANELNRVCKGVYNKPTVSTNALFYLKERGa \\
\hline & GLSAECCRKACSVSELAGYCY \\
\hline \multirow[t]{3}{*}{ ILP PRP } & SPRTLEPEGEAVSEGE \\
\hline & VDLWPLGIELQFPPWTQAPADE \\
\hline & ANQI IESHQPDKPMEQSLGESQRLVFLTGPEASQVVSGLPRV \\
\hline Intocin & CFITNCPPGa \\
\hline \multirow[t]{5}{*}{ Intocin PRP } & SGGLMSQLGRARTCTSCGGGLLGRCIGPDICCGPRIGCFFGSRET \\
\hline & LC \\
\hline & TENMVPITCEFNSDLKPCGRMQEa \\
\hline & CAAPGLCCTENKCEINDDCVVDTTRGEDMS̄TSQRGa \\
\hline & PRFDLLSTSRDSWEEQ \\
\hline \multirow[t]{2}{*}{ Leucokinin } & +SAWAa \\
\hline & FNAWAa \\
\hline \multirow[t]{3}{*}{ Leucokinin PRP } & SDDNKSQKFSGGTENHNNEENQDQFLLW \\
\hline & DDAFHSPESRFHPWLa \\
\hline & SLY $_{(\mathrm{SO} \mathrm{H})}$ EQEGDEEEKSRSQLSSLLQQHQHQQQQQVSQILPNSPDSLTHWGANWDS \\
\hline \multirow[t]{4}{*}{ Neuroparsin } & 4 \\
\hline & 5 \\
\hline & 6 \\
\hline & 7 \\
\hline PDH & NSELINSILGLPKVMNDAa \\
\hline PDH PRP & QDLKYQEREMVAELAQQIYRVAQAPWAGAVGPH \\
\hline \multirow[t]{10}{*}{ Pyrokinin } & LYFAPRLa \\
\hline & SSFSPRPa \\
\hline & GSGFAFSPRLa \\
\hline & GRSAFAFGPRPa \\
\hline & SNFAFAPRPa \\
\hline & ANFAFAPRPa \\
\hline & TNFAFAPRPa \\
\hline & DNFAFAPRPa \\
\hline & TNFAFSPRLa \\
\hline & ATFAFAPRPa \\
\hline \multirow[t]{6}{*}{ Pyrokinin PRP } & VDEDGVSSFPSSPLLHRLGSSAPWGHVAANPMTSLLAGHLNLQPPMHTIQERMS \\
\hline & PLRILTPGVP \\
\hline & NPNMAEVLDERN \\
\hline & DEITNLEEPEDTTSIPYRWWWPLVSV \\
\hline & AEEQTEVDLPYDYVAGDLYDTLDDDEEE IEDEEDEEGNAAVLQD \\
\hline & ADSSSETEQTQAGQTWWFGEAEGTPATTLPPFLPSRLE \\
\hline RPCH & PQLNFSPGWa \\
\hline \multirow[t]{2}{*}{ RPCH PRP } & AAAASGGGGGVGEAVSALHPSVVGAPGGVMPPGSSSSGDSCGPIPVSAVMHIYRLI \\
\hline & $\mathrm{NEAVRLVQCQDEEY}_{(\mathrm{SO} \mathrm{H})} \mathrm{La}$ \\
\hline \multirow[t]{3}{*}{ sNPF } & APPSMRLRFa \\
\hline & DMGWQVAQRSMPSLRLRFa \\
\hline & DVRTPALRLRFa \\
\hline sNPF PRP & VPADY $_{(\text {(Ооз })}$ DSLNDVYDWLADHAVN \\
\hline
\end{tabular}




\begin{tabular}{|c|c|}
\hline & NVDQADPILDHDLV \\
\hline & GATFGEEDMASQEQ \\
\hline SIFamide & GYRKPPFNGSIFa \\
\hline SIFamide PRP & SGTDAVYEPGKSQALASVCQMAMEACTLWFPGAE \\
\hline
\end{tabular}

Peptides highlighted in yellow have been previously identified in C. borealis (see text).

The peptide highlighted in green is likely a known $C$. borealis peptide, but one whose original sequence was misassigned (see text); it is considered a new discovery here.

Peptide family abbreviations: AST-A, allatostatin A; AST-B, allatostatin B; AST-C, allatostatin C, CCAP, crustacean cardioactive peptide; $\mathrm{CHH}$, crustacean hyperglycemic hormone; CPRP, crustacean hyperglycemic hormone precursor-related peptide; DH31, diuretic hormone 31; DH44, diuretic hormone 44; FLP, FMRFamide-like peptide; ILP, insulin-like peptide; PDH, pigment dispersing hormone; RPCH, red pigment concentrating hormone; sNPF, short neuropeptide F; PRP, precursor-related peptide.

Abbreviations in peptide structures: a, amidated C-terminus; +, likely partial peptide with additional unknown amino acids; $\mathrm{pQ} / \mathrm{pE}$, pyroglutamic acid; $\underline{\mathrm{C}}$, disulfide bonded cysteine (see text for descriptions of bonding partners for peptides with more than one disulfide bridge); $\mathrm{Y}_{(\mathrm{SO} 3 \mathrm{H})}$, sulfated tyrosine. It should be noted that that prediction of the tyrosine residue sulfation state and disulfide bridging between cysteines was done only for full-length peptides.

${ }^{1}$ GSWPPSAPRTPATALIAAPFLQGLATPRSPARSWQDKVMTQHRQHHQDQHLHHLEQQQQQQQQQQVFPAVYDEVALPRIPASLH

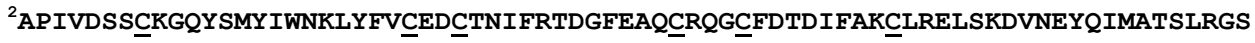

${ }^{3}$ PLSLPPHHRLAPHNPDLI PDDQALALMSDPASRYEEGLLNELENPHSSSSYHLKQLISELADAITAAEELEGGAYGAPLPAEIAEAIVA AEGIEGGADGRPLPSDVAEAIAEAEAAAVMGGGLARPWED

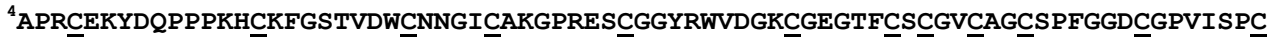

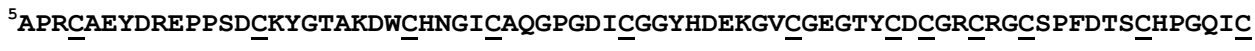

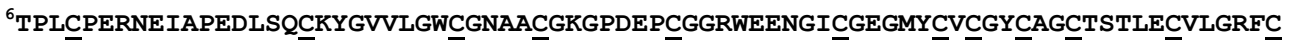

${ }^{7}$ GPVCASLNEVLPEMLPPCRHGVVRDYCDNAMCMKGPGETCGGRWNENGFCGKGLYCVCGYCAGCSKDLQCALGRFC 
A. Prepro-allatostatin C I (from GEFB01008004) MMPCPAHLVVVLALALALSHALPAKKVPDAPKEVSKGHEGGRLQKRAAASSASDTSEEELAALKDI ILARLAAELDDSWQDLPSFKRDLLKGDMDEE EDDEGDEGSRREDVKKKRMFAPLSGLPGNLRTIKRQIRYHQCYFNPISCFRRK

$\downarrow$ Signal peptidase (cleavage locus highlighted above)

LPAKKVPDAPKEVSKGHEGGRLQKRAAASSASDTSEEELAALKDI ILARLAAELDDSWQDLPSFKRDLLKGDMDEEEDDEGDEGSRREDVKKKRMFA PLSGLPGNLRTIKRQIRYHQCYFNPISCFRRK

$\downarrow$ Prohormone convertase (cleavage loci highlighted above)

LPAKK VPDAPKEVSKGHEGGRLQKR AAASSASDTSEEELAALKDIILARLAAELDDSWQDLPSFKR DLLKGDMDEEEDDEGDEGSRR EDVKKKR MFAPLSGLPGNLRTIKR QIRYHQCYFNPISCFRRK

$\downarrow$ Carboxypeptidase (cleavage loci highlighted above)

LPA VPDAPKEVSKGHEGGRLQ AAASSASDTSEEELAALKDIILARLAAELDDSWQDLPSF DLLKGDMDEEEDDEGDEGS EDV MFAPLSGLPGNLRTI QIRYHQCYFNPISCF

$\downarrow$ Glutaminyl cyclase (cyclization locus highlighted above)

PQIRYHQCYFNPISCF

$\downarrow$ Enzymatic disulfide bond formation (bridged cysteines highlighted above)

PQIRYHQCYFNPISCF

B. Prepro-diuretic hormone 31 (from GEFB01004916)

MNNLGVVFVSLVAVFVLLSSVNASPINREPSRAVVEIDDPDYVLELLTRFSNSI IRAKELEKFVRSSSGAKRGLDMGLGRGF SGSQAAKHLMGIAAA NYAGGPGRRKRESEAATIDQHHDDHHLAVQQHSAAAAAAAPAGLSPHSS

$\downarrow$ Signal peptidase (cleavage locus highlighted above)

SPINREPSRAVVE IDDPDYVLELLTRFSNS I IRAKELEKFVRSSSGAKRGLDMGLGRGF SGSOAAKHLMGIAAANYAGGPGRRKRESEAATIDQHHD DHHLAVQQHSAAAAAAAPAGLSPHSS

$\downarrow$ Prohormone convertase (cleavage loci highlighted above)

SPINREPSRAVVEIDDPDYVLELLTRFSNSIIR AKELEKFVRSSSGAKR GLDMGLGRGFSGSQAAKHLMGIAAANYAGGPGRRKR ESEAATIDQHHDDHHLAVQQHSAAAAAAAPAGLSPHSS

$\downarrow$ Carboxypeptidase (cleavage loci highlighted above)

SPINREPSRAVVEIDDPDYVLELLTRFSNSII AKELEKFVRSSSGA GLDMGLGRGFSGSQAAKHLMGIAAANYAGGPG

$\downarrow$ Peptidylglycine- $\alpha$-amidating monooxygenase (amidation locus highlighted above)

SPINREPSRAVVEIDDPDYVLELLTRFSNSII GLDMGLGRGFSGSQAAKHLMGIAAANYAGGPamide

$\downarrow$ Tyrosylprotein sulfotransferase (tyrosine targets highlighted above)

SPINREPSRAVVEIDDPDY (SО3H) VLELLTRFSNSII

C. Prepro-short neuropeptide F (from GEFB01013717)

MGMSGVKCWVALACCCILLCQLTTAVPADYDSLNDVYDWLADHAVNRRAPPSMRLRFGKRDMGWQVAQRSMPSLRLRFGKRNVDQADPILDHDLVRK DVRTPALRLRFGKRGATFGEEDMASQEQ

$\downarrow$ Signal peptidase (cleavage locus highlighted above)

VPADYDSLNDVYDWLADHAVNRRAPPSMRLRFGKRDMGWQVAQRSMPSLRLRFGKRNVDQADPILDHDLVRKDVRTPALRLRFGKRGATFGEEDMAS QEQ

$\downarrow$ Prohormone convertase (cleavage loci highlighted above)

VPADYDSLNDVYDWLADHAVNRR APPSMRLRFGKR DMGWQVAQRSMPSLRLRFGKR NVDQADPILDHDLVRK DVRTPALRLRFGKR GATFGEEDMASQEQ

$\downarrow$ Carboxypeptidase (cleavage loci highlighted above)

VPADYDSLNDVYDWLADHAVN APPSMRLRFG DMGWQVAQRSMPSLRLRFG NVDQADPILDHDLV DVRTPALRLRFG

$\downarrow$ Peptidylglycine- $\alpha$-amidating monooxygenase (amidation locus highlighted above)

VPADYDSLNDVYDWLADHAVN APPSMRLRFamide DMGWQVAQRSMPSLRLRFamide DVRTPALRLRFamide

$\downarrow$ Tyrosylprotein sulfotransferase (tyrosine targets highlighted above)

VPADY $_{(\text {(Ооз }}$ DSLNDVYDWLADHAVN 
A. Prepro-allatostatin A (internal fragment proteins from GEFB01005316) +MGIAARTMISGLVRETPMPLGLENVLVLTPSGLERENHMAGPYSFGLGKREPYAFGLGKRPATDLYAFGLGKRDPYAFGLGKRPADLYEFGLGKRG DPYAFGLGKRD PYAFGLGKRPDMYAFGLGKRSSGQYAFGLGKRPSMYAFGLGKRDPYAFGLGKRPDMYGFGLGKRGSGQYAFGLGKKAGQYSFGLGK RSPSDVSDSYTLGRRSGSYSFGLGKRGGAYSFGLGKRGGAYSFGLGKRDRPYSFGLGKRETIEEDEDDHTKMAADNKALPVPPSSSSSSSSSS++EE AAEIEDEYDQLGFGKRHS PSYASSDFGLGKRAPQPYAFGLGKRAGLYSYGLGKKSDMYSFGLGKKSGSYNFGLGKRSVRDVGSEEEDK++EVRKRIS DEEEEEEDKRTDSQYDNYNKRPRAYSFGLGKRKQEDVGFSKRPRDYAFGLGKRDYDDSDVEKRPKTYSFGLGKRDQDSDLEKRQRAYSFGLGKRDDD SDVEKRQRAYSFGLGKREDDSDIEKRLRAYSFGLGKREDDSDVEKRQRAYSFGLGKREDDSDVEKRQRDYSFGLGKRGYDSEDEDNQLFGFGLGKRP RTYSFGLGKRADEEDDEEEEEEEDEEEGLDVDVVEDLAKRALGVYGDSRQNYDFGLGKRDPYAFGLGKRAGPYSFGLGKREPYGWSLLLWAWQERTL CIRAWKEASNRLIRIRAWQKRPLRFRAWQTTCRSL+

B1. Prepro-allatostatin B I (N-terminal partial protein from GEFB01009802)

MQLATLTATLLTLLAAAAAQDEGSGLAGAQAKRAGWSSMRGAWGKRTPDDTPEHGLQVSEDKRNNNWSKFQGSWGKRGEEIQDAEEKRGNWNKFQGS WGKRADDMTEEAALQAAEDKRGGWNKFQGSWGKRGDEVASEDDFQDGEDKRTSWGKFQGSWGKRQDDLIHLQDLEDKRNNWSKFQGSWGKRAGWSSL Q+

B2. Prepro-allatostatin B II (C-terminal partial protein from GEFB01004713) +GTWGKRSGKWSNLRGAWGKRVPNDWAHFRGSWGKRTPDTLISA

C. Prepro-allatostatin C II (C-terminal partial protein from GEFB01014354) +LEDDGTLDAALINYLFAKQLVQRLRTPSEVSREAQRKRSYWKQCAFNAVSCFGKRK

D. Prepro-CCHamide (from GEFB01009198)

MQTCVRISTLLLLLLPYLLVLTPATQAHGPVKVGCLNYGHSCLGAHGKRGSWPPSAPRTPATALLAPFLQGLATPRSPARSWQDKVMTQHRQHHQDQ HLHHLEQQQQQQQQQQVF PAVYDEVALPRI PASLHRALPAQVKPDAAPLEEEDDLLYYTTYEDDYGDHRAKRSVDKTEEKKALPTRASVSCLLFSRR C

E. Prepro-crustacean cardioactive peptide (from GEFB01016342)

MKIWSTSWSGRAGLMTAGTILLLVCLAVHVQARPVTLRDIDSLLERKIKRPFCNAFTGCGKKRSD PKLEGLASGSELNDNKNVLAEARLWEQLQSEM ETMRLLASRIDGRPTYRRKRSLNHPQHDCTHSAQTIDHKVTCTQL

F. Prepro-crustacean hyperglycemic hormone (from GEFB01007482)

MFGKMQTMAAVLLVVMVIVLKTGGGAAGPVYPQHTASPVQSQALPGEAKQLRRWKRAPIVDSSCKGQYSMYIWNKLYFVCEDCTNIFRTDGFEAQCR QGCFDTDIFAKCLRELSKDVNEYQIMATSLRGS

G. Prepro-diuretic hormone 44 (from GEFB01005116)

MVLARLVAVLAVVCVGARGSTGLSLEGVRGAHGPPRPLSLPPHHRLAPHNPDLI PDDQALALMSDPASRYEEGLLNELENPHSSSSYHLKQLISELA DAITAAEELEGGAYGAPLPAEIAEAIVAAEGIEGGADGRPLPSDVAEAIAEAEAAAVMGGGLARPWEDRNPRYMRFTEYQPRNSAEANNNSNNRKAR DSRNSRSVTNNNTNNNNNNNSLTSSTSTGTSTT PNNNNNNNNKLANNHNSGMFKRAWPHSFSRRRSSGLSLSIDASMKVLREALYLEIARKKQRQQL QRAQHNKALLNTIGKRDVASQLVGVDQGVALQNARN

H. Prepro-FMRFamide-like peptide (C-terminal partial protein from GEFB01000266)

+SSSEEDKHRFGRSEEDKRGGRNFLRFGRGDSSSVEDMDVLPETEDTIEKRNRNFLRFGRNRNFLRFGRSDAEEFGLPGGPLAFDNNVQEDDLTDYP MEEKRGAHKNYLRFGRGNRNFLRFGRSENRNFLLRFGRSVDRQLSEQKTRDAPVAPTATIHSPAKTQESHRSKRAASPYNYVVLPSHGPAAWAQNFQP DQDDDLEEAVDGPDVAKRAYNRSFLRFGRDRNFLRFGKRSDEDDASDMMMMDPASYNRYVRAPQRNFLRFG

I. Prepro-GSEFLamide (N-terminal partial protein from GEFB01024463)

MVQGTTCLTKRIVVLSCVSCVLSAVLHTTHADEGVGEVAKRGGGSSRDPMLRYLLVAMAQPGPRYAAPQILSRGVRRIGSEFLGKRSPVVESPEVVE SPEPGKTCESGSCVTEEDHDHADDLKKEQLSFTGQYNEQEGSDGLQDEPDKRVLGALSRSRLARYLSLLMNKKMGSEFLGKRAVG+

J. Prepro-HIGSLYRamide (N-terminal partial protein from GEFB01004531)

MTRHQRLFHRLIPPLVLLIALLMPCCSAQDAAAAPVASQQQEEQQPAREKRFLGSVLRQDGRLPIWGFKRSFGVQQDSDSDHNDALTLPAASPVEGIP SQSPQTQALEKRHLSSLARNNAYPKDLREKKYFASLLKSRAFGDDSKLIPHNAAGDSEPHLQKRFYASLLKSDSPPQTAYLNSMFYRQDKRHYSSLL RNGPLPFIQDKRHFGSLLKSPSYRAISIPGKRSPNAVED PEDNPVRELEDIRDLSSGFDGDLDLHDRLVAAGVISPGLSVRGDTQDLEALLTAWYAA ATSGQDKRHIGSLYRGKKDEDSLYQDLNEDKRHIGSLYRGKKEDNLYHDLSEDKRHIGSLYLSEDKRHIGSLYRGKKNEDNLLNLSEDKRHIGSLYR GKKDEDNSYYDLNEDKRHIGSLYRGKKDEDNSYYDLNEDKRHIGSLYRGKKDEDNSYYDLNEDKRHIGSLYRSKKDEDNSYYDLNEDKRHIGSLYRG KKDEDNLYYDLNEDKRHIGSLYRGKKDEDNSYYDLNEDKRHIGSLYRGKKDEDNSYYDLNEDKRHIGSLYRGKKEDNLYHDLSEDKRHIGSLYRGKK DEDNLYHELSEDKRHIGSLYRGKKEDNLYHDLSEDKRHIGSLYRGKKDEDNMYQNLLEDKRHIGSLYRGKKDEDNFQGLSEDKRHIGSLYRGKKDED NSQNLAEDKRHIGSLYRDKKDEDNSQNLSEDKRHYSSLLRGKKDEDNTNSLSEDKRHIGSLYRGKKDEDNTNSLSEDKRHI+

K. Prepro-insulin-like peptide (from GEFB01034529)

MKMKILLLVVVTAMQAGRTLGSPRTLPEGEAVSEGERRLCGWKLANELNRVCKGVYNKPTVSTNALFYLKERGGKRVDLWPLGIELQFPPWTQAPAD ERRANQIIESHQPDKPMEQSLGESQRLVFLTGPEASQVVSGLPRVKRGLSAECCRKACSVSELAGYCY 
L. Prepro-intocin (from GEFB01036259)

MQAGMAVTVVVTLLVGGTAACFITNCP PGGKRSGGLMSOLGRARTCTSCGPGLLGRCIGPDICCGPRIGCFLGSRETRLCRTENMVPITCFNSDLKP CGRMQEGRCAAPGLCCTENKCEINDDCVVDTRGEDMSTSQRGGRPRFDLLSTSRDSWEEQ

M. Prepro-leucokinin (C-terminal partial protein from GEFB01013465)

+SAWAGKRKFNAWAGKRSDDNKSQKFSGGTENHNNEENQDQFLLWKRDDAFHSPESRFHPWLGKRSLYEQEGDEEEKSRSQLSSLLQQHQHQQQQQV SQILPNSPDSLTHWGANWDS

N1. Pre-neuroparsin I (from GEFB01000285)

MASCCRAAAFVLACSYIMLFFOEGRAAPRCEKYDQPPPKHCKFGSTVDWCNNGICAKGPRESCGGYRWVDGKCGEGTFCSCGVCAGCSPFGGDCGPV ISPC

N2. Pre-neuroparsin II (from GEFB01009505)

MPFTATATLILTSSLFLLLLLLQEGSAAPRCAEYDREPPSDCKYGTAKDWCHNGICAQGPGDICGGYHDEKGVCGEGTYCDCGRCRGCSPFDTSCHP GQIC

N3. Pre-neuroparsin III (from GEFB01037835)

MKCSGISGVVSCSFLLLLLVQNAAATPLCPERNEIAPEDLSQCKYGVVLGWCGNAACGKGPDEPCGGRWEENGICGEGMYCVCGYCAGCTSTLECVL GRFC

N4. Pre-neuroparsin IV (from GEFB01000829)

METSTRSYIFLYIVSSTLLLLLPGGSEGGPVCASLNEVLPEMLPPCRHGVVRDYCDNAMCMKGPGETCGGRWNENGFCGKGLYCVCGYCAGCSKDLQ CALGRFC

O. Prepro-pigment dispersing hormone (from GEFB01009346)

MRSAVVVAVLVVVALTALLTQGQDLKYQEREMVAELAQQIYRVAQAPWAGAVGPHKRNSELINSILGLPKVMNDAGRR

P. Prepro-pyrokinin (from GEFB01006571)

MHCNPARPLTSLVCLALVVCASLVQGVDEDGVSSFPSSPLLHRLGSSAPWGHVAANPMTSLLAGHLNLQPPMHTIQERMSRPLRILTPGVPKRLYFA PRLGKRNPNMAEVLDERNRRDEITNLEEPEDTTSI PYRWWWPLVSVRRSSFSPRPGKRAEEQTEVDLPYDYVAGDLYDTLDDDEEEIEDEEDEEGNA AVLQDKRGSGFAFSPRLGKRGRSAFAFGPRPGKKSNFAFAPRPGKKANFAFAPRPGKRTNFAFAPRPGKKDNFAFAPRPGKKTNFAFSPRLGKKATF AFAPRPGKRADSSSETEQTQAGQTWWFGEAEGTPATTLPPFLPSRLE

Q. Prepro-red pigment concentrating hormone (from GEFB01008309)

MVRRTGVTLIVVALVVVALVSSVSAQLNFSPGWGKRAAAASGGGGGVGEAVSALHPSVVGAPGGVMPPGSSSSGDSCGPIPVSAVMHIYRLIRNEAV RLVQCQDEEYLG

R. Prepro-SIFamide (from GEFB01002741)

MSVQMRVVVAVAVVVVVLALLSS PVSAGYRKPPFNGSIFGKRSGTDAVYEPGKSQALASVCQMAMEACTLWFPGAEKK 